ISBN 978-623-6833-94-0 (PDF)

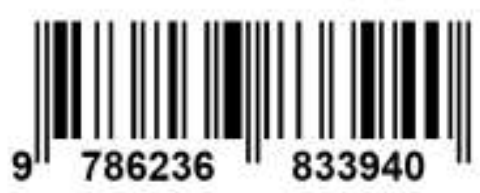

\section{STATISTIK DI}

FASILITASLAYANAN KESEHATAN

Umi Khoirun Nisak, S.KM., M.Epid

Cholifah, M.Kes

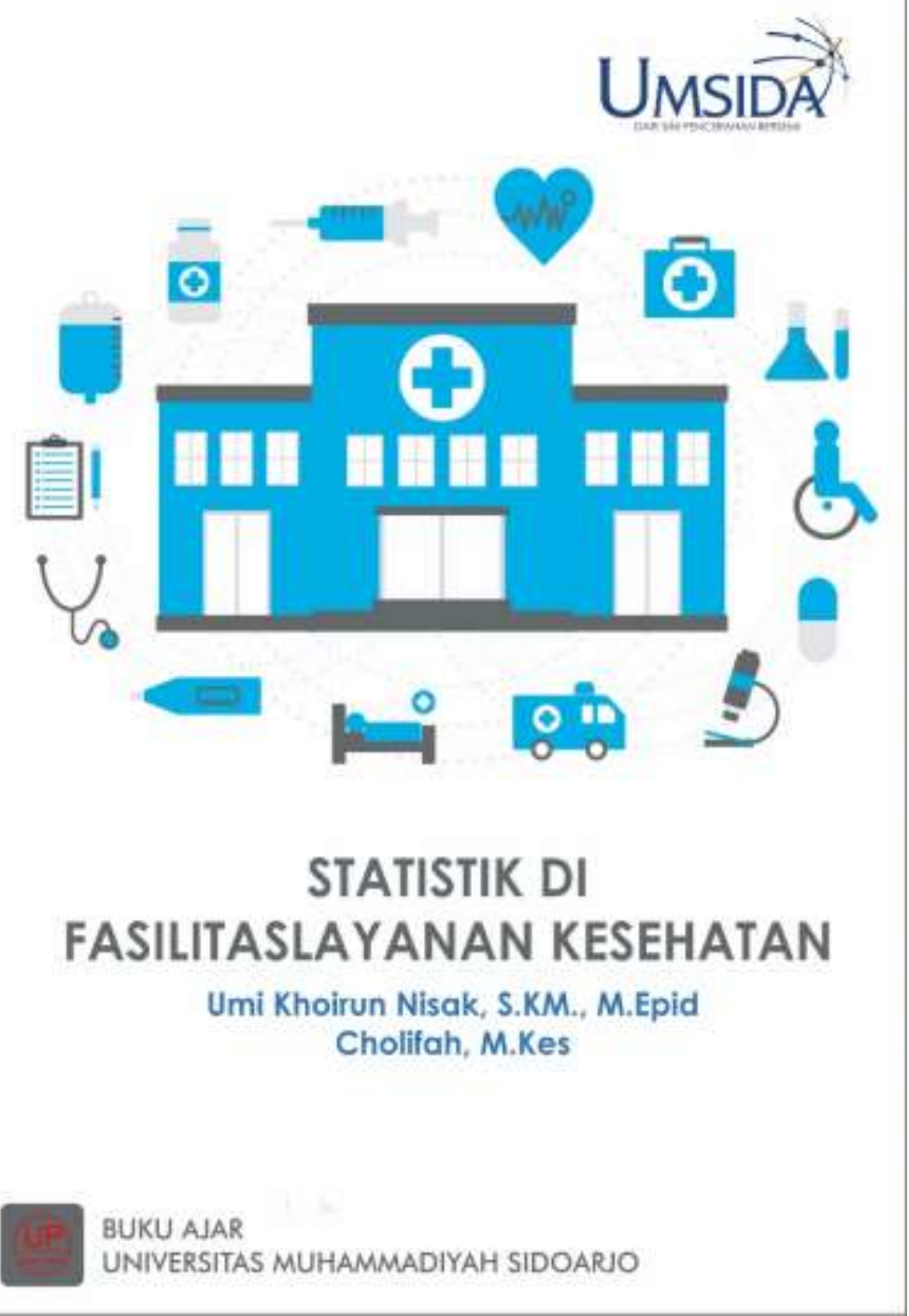




\title{
BUKU AJAR \\ STATISTIK DI FASILITAS PELAYANAN \\ KESEHATAN
}

\author{
Oleh \\ Umi Khoirun Nisak., S.KM., M. Epid \\ Cholifah., SST., M. Kes
}

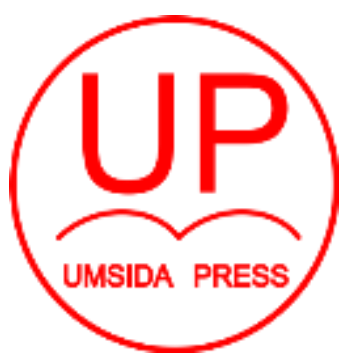

Diterbitkan oleh

UMSIDA PRESS 


\section{BUKU AJAR \\ STATISTIK DI FASILITAS PELAYANAN KESEHATAN}

\section{Penulis:}

Umi Khoirun Nisak., SKM., M. Epid

Cholifah., SST., M. Kes

\section{ISBN :}

978-623-6833-94-0

\section{Editor:}

Sri Mukhoddim Faridah Hanum, M.Kes.

\section{Design Sampul dan Tata Letak:}

Mochammad Nashrullah, S.Pd.

Amy Yoga Prajati, S.Kom.

Penerbit:

UMSIDA Press

Anggota IKAPI No. 218/Anggota Luar Biasa/JTI/2019

Anggota APPTI No. 0020181092017

Redaksi

Universitas Muhammadiyah Sidoarjo

Jl. Mojopahit No 666B

Sidoarjo, Jawa Timur

Cetakan Pertama, September 2020

OHak Cipta dilindungi undang undang

Dilrang memperbanyak karya tulis ini dengan sengaja, tanpa ijin tertulis dari penerbit. 


\section{KATA PENGANTAR}

Puji syukur atas kehadirat Allah SWT yang telah melimpahkan rahmat, berkah, karunia, dan hidayah-Nya kepada penulis sehingga dengan izin-Nya penulis dapat menyelesaikan buku yang berjudul Biostatistik Rekam Medis Dan Informasi Kesehatan.

Penyusunan dan pembahasan buku ini mengacu pada kurikulum, Mata Kuliah Statistik di Fasilitas Pelayanan Kesehatan di Program Studi Manajemen Informasi Kesehatan. Buku ini berisi materi-materi khusus tentang konsep Statistik dan Pelaporan di Fasilitas Pelayanan Kesehatan yang bermanfaat bagi Mahasiswa manajemen Informasi Kesehatan. Penulis berharap buku ini dapat menambah wacana buku ilmu pengetahuan pada bidang kesehatan, khususnya bagi mahasiswa dan praktisi rekam medis dan informasi kesehatan.

Dalam kesempatan ini, penulis mengucapkan terima kasih kepada semua pihak yang telah banyak membantu, serta dukungan luar biasa yang diberikan kepada penulis sehingga buku ini dapat terselesaikan.

Penulis menyadari bahwa buku ini masih jauh dari sempurna, oleh karena itu penulis sangat mengharapkan saran dan kritik yang sifatnya membangun dari pembaca dan semua pihak sehingga buku ini kelak menjadi lebih sempurna dan bermanfaat. 


\section{DAFTAR ISI}

HALAMAN SAMPUL

KATA PENGANTAR

DAFTAR ISI

BAB I PENGANTAR STATISTIK RUMAH SAKIT

A. Pengertian Rumah Sakit ........................................ 1

B. Pengertian Statistik Rumah Sakit ............................. 2

C. Unsur-Unsur Dalam Statistik Rumah Sakit .................. 3

D. Sumber Data Statistik Rumah Sakit.......................... 7

E. Review Matematika dalam Statistik Pelayanan Kesehatan.

\section{BAB II SENSUS PASIEN}

A. Pengertian Sensus Data......................................... 21

B. Pasien Transfer...................................................... 26

C. Pasien Masuk dan Keluar pada Hari yang Sama....... 27

D. Rekapitulasi Sensus............................................ 29

E. Rerata Sensus Pasien............................................ 30

F. Rerata Sensus Bayi Baru Lahir................................ 31

G. Rerata Sensus Pasien ICU..................................... 32

\section{BAB III EFISIENSI PENGGUNAAN TEMPAT TIDUR}

A. Jumlah Tempat Tidur.......................................... 38

B. Bed Occupancy Ratio (BOR)................................... 40

C. Lama Rawat/Length of Stay (LOS)............................ 43

D. Turn Over Interval (TOI)......................................... 50

E. Bed Turn Over (BTO)............................................. 52

\section{BAB IV GRAFIK BARBER JHONSON}

A. Pengertian Grafik Barber Jhonson........................... 61

B. Manfaat Grafik Barber Johnson................................ 61

C. Format Grafik Barber Johnson.................................. 62

D. Cara Membuat Grafik Barber Johnson....................... 64

E. Cara Menggunakan Grafik Barber Johnson.................66 66

F. Cara Membaca Grafik Barber Johnson....................... 68 


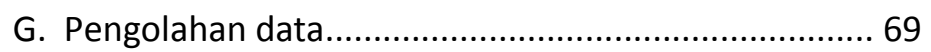

\section{BAB V STATISTIK MORTALITAS}

A. Pengertian Statistik Mortalitas................................... 78

B. Rumus dan Batasan dalam Menghitung Statistik

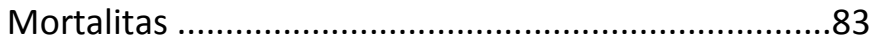

C. Gross Death rate (GDR) ....................................... 84

D. Net Death rate (NDR) ......................................... 86

E. Postoperative Death Rate........................................... 87

F. Anesthesia Death Rate......................................... 88

G. Maternal Death Rate............................................... 89

H. Newborn Mortality Rate........................................ 92

I. Fetal Death Rate.................................................. 93

DAFTAR PUSTAKA

BIODATA PENULIS 


\section{BATANG TUBUH DAN}

\section{SUB-CAPAIAN PEMBELAJARAN MATA KULIAH}

\begin{tabular}{|c|c|}
\hline BAB & Sub-Capaian Pembelajaran Mata Kuliah \\
\hline $\begin{array}{l}\text { BAB I } \\
\text { PENGANTAR } \\
\text { STATISTIK } \\
\text { RUMAH SAKIT }\end{array}$ & $\begin{array}{l}\text { 1. Mahasiswa mampu memahami Pengertian Rumah } \\
\text { Sakit } \\
\text { 2. Mahasiswa mampu memahami Pengertian Statistik } \\
\text { Rumah Sakit } \\
\text { 3. Mahasiswa mampu memahami Unsur-Unsur Dalam } \\
\text { Statistik Rumah Sakit } \\
\text { 4. Mahasiswa mampu memahami Sumber Data } \\
\text { Statistik Rumah Sakit } \\
\text { 5. Mahasiswa mampu memahami matematika dan } \\
\text { statistic pelayanan kesehatan }\end{array}$ \\
\hline $\begin{array}{l}\text { BAB II } \\
\text { SENSUS DATA }\end{array}$ & $\begin{array}{l}\text { 1. Mahasiswa mampu memahami Pengertian Sensus } \\
\text { Data } \\
\text { 2. Mahasiswa mampu memahami Pasien Transfer } \\
\text { 3. Mahasiswa mampu memahami dan mampu } \\
\text { menghitung Pasien Masuk dan Keluar pada Hari } \\
\text { yang Sama } \\
\text { 4. Mahasiswa mampu memahami dan melakukan } \\
\text { Rekapitulasi Sensus } \\
\text { 5. Mahasiswa mampu memahami dan menghitung } \\
\text { Rerata Sensus Pasien } \\
\text { 6. Mahasiswa mampu memahami dan menghitung } \\
\text { Rerata Sensus Bayi Baru Lahir }\end{array}$ \\
\hline $\begin{array}{l}\text { BAB III } \\
\text { EFISIENSI } \\
\text { PENGGUNAAN } \\
\text { TEMPAT } \\
\text { TIDUR }\end{array}$ & $\begin{array}{l}\text { 1. Mahasiswa mampu memahami dan menghitung } \\
\text { Jumlah Tempat Tidur } \\
\text { 2. Mahasiswa mampu memahami dan menghitung Bed } \\
\text { Occupancy Ratio (BOR) } \\
\text { 3. Mahasiswa mampu memahami dan menghitung } \\
\text { Lama Rawat/Length of Stay (LOS) } \\
\text { 4. Mahasiswa mampu memahami dan menghitung } \\
\text { Turn Over Interval (TOI) }\end{array}$ \\
\hline
\end{tabular}




\begin{tabular}{|c|c|c|}
\hline & & $\begin{array}{l}\text { Mahasiswa mampu memahami dan menghitung Bed } \\
\text { Turn Over (BTO) }\end{array}$ \\
\hline $\begin{array}{l}\text { BAB IV } \\
\text { GRAFIK } \\
\text { BARBER } \\
\text { JHONSON }\end{array}$ & 1. & $\begin{array}{l}\text { Mahasiswa mampu memahami Pengertian Grafik } \\
\text { Barber Jhonson } \\
\text { Mahasiswa mampu memahami Manfaat Grafik } \\
\text { Barber Johnson } \\
\text { Mahasiswa mampu memahami dan membuat } \\
\text { Format Grafik Barber Johnson } \\
\text { Mahasiswa mampu memahami Cara Membuat } \\
\text { Grafik Barber Johnson } \\
\text { Mahasiswa mampu memahami Cara Menggunakan } \\
\text { Grafik Barber Johnson } \\
\text { Mahasiswa mampu memahami Cara Membaca } \\
\text { Grafik Barber Johnson } \\
\text { Mahasiswa mampu memahami Pengolahan data }\end{array}$ \\
\hline $\begin{array}{l}\text { BAB V } \\
\text { STATISTIK } \\
\text { MORTALITAS }\end{array}$ & 8. & $\begin{array}{l}\text { Mahasiswa mampu memahami Pengertian Statistik } \\
\text { Mortalitas } \\
\text { Mahasiswa mampu memahami Rumus dan Batasan } \\
\text { dalam Menghitung Statistik Mortalitas } \\
\text { Mahasiswa mampu memahami Gross Death rate } \\
\text { (GDR) } \\
\text { Mahasiswa mampu memahami Net Death rate } \\
\text { (NDR) } \\
\text { Mahasiswa mampu memahami Postoperative } \\
\text { Death Rate } \\
\text { Mahasiswa mampu memahami Anesthesia Death } \\
\text { Rate } \\
\text { Mahasiswa mampu memahami Maternal Death } \\
\text { Rate } \\
\text { Mahasiswa mampu memahami Newborn Mortality } \\
\text { Rate } \\
\text { Mahasiswa mampu memahami Fetal Death Rate }\end{array}$ \\
\hline
\end{tabular}




\section{Tujuan Instruksional Umum}

Setelah mempelajari bagian ini, pembaca diharapkan mampu memahami pengertian, lingkup, tujuan, dan pemanfaatan sstatistic Rumah sakit, serta teknik perhitungan dasar pada statistik

\section{Tujuan Instruksional Khusus}

1. Memahami mengenai pengertian statistic, dan alas an mempelajari statistik di fasilitas pelayanan Kesehatan

2. Mengidentifikasi sumber data

3. Memahami perbedaan data dan informasi, validitas, dan realibilitas

4. Memahami dan mengidentifikasi pengguna statistic di fasilitas pelayanan Kesehatan

5. Memahami perhitungan dalam statistic dasar seperti bilangan bulat, pecahan, desimal, persentase, konversi bentuk bilangan, rasio, proporsi, dan rate serta standar deviasi

\subsection{Pengertian Rumah Sakit}

Pengertian rumah sakit berdasarkan SK Menteri Kesehatan RI No.983/Menkes/SK/XI/1992 menyebutkan bahwa rumah sakit umum adalah rumah sakit yang memberikan pelayanan kesehatan yang bersifat dasar, spesialistik dan subspesialistik.

Rumah sakit adalah suatu institusi pelayanan kesehatan yang kompleks, padat pakar, dan padat modal. Kompleksitas ini 
muncul karena pelayanan rumah sakit meyangkut berbagai fungsi pelayanan, pendidikan, dan penelitian, serta mencakup berbagai tingkatan maupun jenis disiplin, agar rumah sakit mampu melaksanakan fungsi yang professional baik dibidang teknis medis maupun administrasi kesehatan. untuk menjaga dan meningkatkan mutu rumah sakit harus mempunyai suatu ukuran yang menjamin peningkatan mutu di semua tingkatan.

Rumah sakit adalah suatu organisassi yang melalui tenaga medis professional yang terorganisir serta sarana prasarana kedokteran yang permanen menyelenggarakan pelayanan kedokteran, asuhan keper-awatan yang berkesinambungan, diagnosis serta pengobatan penyakit yang diderita oleh pasien (AZWAR, 1988).

Rumah sakit adalah tempat di mana orang sakit mencari dan menerima pelayamam Ikedokteran, serta tempat di. mana pendidikan klinik untuk mabaslswa kedokteran, perawat, dan berbagai tenaga profesi Kesehatan lainya diselenggarakan (Wolper, 2010).

Rumah sakit adalah pusat di mana pelayanan Kesehatan masyarakat, pendidikan serta penelitian kedokteran diselenggarakan (AZWAR, 1988).

\subsection{Pengertian Statistik Rumah Sakit}

Statistika rumah sakit adalah kumpulan data berbentuk angka yang menggambarkan informasi kondisi suatu rumah sakit yang digunakan untuk pengambilan keputusan dan bersumber pada data rekam medis.

\subsection{Unsur-Unsur Dalam Statistik Rumah Sakit}

Unsur-unsur dalam statistic Rumah sakit adalah sebagai berikut: 
1. Pengumpulan data

2. Pengolahan data

3. Penyajian data

4. Analisa \& Interprestasi data

\section{a. Pengumpulan Data Rekam Medis}

Pengumpulan data rekam medis dapat dilakukan dengan mengumpulkan lembaran sensus harian baik rawat jalan, rawat inap dan gawat darurat. Pada saat mengecekjumlah penderita masuk dan keluar sesuai dengan contoh card yang diterima dan sesuai dengan jumlah medical record yang dikirim dari bangsal, hal-hal berikut harus diteliti:

1. Bahwa jumlah sisa penderita yang masih tinggal dibangsal (dirumah sakit) hari sebelumnya harus sesuai dengan jumlah penderita sisa dalam sensus hari berikutnya.

2. Benarnya perhitungan yang dibuat oleh setiap bangsal.

3. Semua lembaran sensus harian disusun menurut bangsalbangsal.

4. Satukan angka tersebut kesatu lembaran sensus harian untuk seluruh rumah sakit.

Pindahkan hasil sensus seluruh rumah sakit ke lembaran sensus bulanan/rekap bulanan yang disesuaikan untuk tiap-tiap tanggal. Tentukan data yang dibutuhkan serta cara mendefinisikannya, kebanyakan data ini harus diringkaskan dalam bentuk catatan medis yang rapi. Pengumpulan data di Rumah Sakit biasanya dilakukan secara berurutan pada berhentinya perawatan pasien, tapi mungkin dimulai bersamaan selama masa opname. Data-data yang diperlukan mungkin dituliskan dalam lembar kerja, dimasukkan pada iktisar pada sejumlah input dalam sistem proses dan komersial, atau langsung dimasukkan kedalam database baik melalui server cloud maupun lokal. Kop berkolom untuk pelayanan merupakan 
prosedur yang digunakan dalam pengumpulan data manual dalam bentuk lembar kerja, hasil dan data pilihan dengan dimasukkan dengan tangan untuk masing masing pasien telah digantikan semuanya tetapi beberapa Rumah Sakit kecil dengan iktisar data atau input terbaru kedalam komputer. Apapun metodologinya, suatu prosedur harus dikembangkan untuk menguraikan isi rekam medis.

Dalam sistem tinjauan bersama personil mengunjungi bagian perawatan untuk mengumpulkan data dari rekaman. Data dikumpulkan dalam waktu berkala dimulai dari hari pertama sampai ketiga setelah pasien masuk, atau sesuai ketentuan waktu pengambilan yang disepakati setiap rumah sakit. Sedikit data keluarnya pasien yang direkam. Pengumpulan data dilakukan pada keluarnya pasien. Pengembangan prosedur dalam menerima semua rekaman pasien yang keluar dari Rumah Sakit di pagi hari berikutnya. Daftar pasien yang keluar dari Rumah Sakit setiap hari berfungsi sebagai alat untuk memantau rekaman yang diterima. Bagian penerimaan, bagian tanggungan pasien, pelayanan perawatan atau bagian informasi kesehatan bisa bertanggung jawab mempersiapkan daftar masuknya pasien, data mengenai daftar keluarnya pasien baik berupa hardfile maupun softfile kemudian didistribusikan tiap hari sebagai laporan sensus dan bagian dari sistem proses data.

\section{Hubungan Statistik Pelayanan Kesehatan dengan Rekam Medis}

Hubungan statistik rumah sakit dengan rekam medis sangatlah erat karena statistic berkaitan dengan pelaporan RS dan Rekam medis. Selain itu, syarat akreditasi rumah sakit harus 
ada bagian/unit rekam medis. Unit rekam medis selain memberikan pelayanan secara langsung kepada pasien, unit rekam medis juga berperan penting di dalam menyediakan data atau informasi tentang kegiatan pelayanan di rumah sakit, data yang dihasilkan dari unit rekam medis tersebut dapat digunakan untuk mengolah data yang selanjutnya dapat digunakan untuk menyusun pelaporan rumah sakit.

Gambar 1.1 Hubungan Statistik Rumah Sakit dengan Rekam Medis

\footnotetext{
Pemanfaatan Data Rekam Medis untuk Statistik Rumah Sakit

Data rekam medis yang dihasilkan dari pelayanan kesehatan pada pasien dapat dimanfaatkan untuk bermacam-macam kegiatan di rumah sakit, salah satunya yaitu untuk penghitungan statistik rumah sakit. Data statistik rumah sakit dihasilkan dari beberapa unit pelayanan di rumah sakit antara lain dari:
} 
1. TPPRJ \{Tempat Penerimaan Pasien Rawat Jalan)

2. TPPRI \{Tempat Penerimaan Pasien Rawat Inap)

3. UGD

4. Poliklinik/URJ (Unit Rawat Jalan)

5. Bangsal rawat inap/URI (Unit Rawat inap)

6. Apotik

7. Keuangan

8. Instalasi Gizi

9. Laboraturium

10. RO/Radiologi

11. Bagian Alkes/peralatan kesehatan

12. Bagian Kesling (Kesehatan Lingkungan)

13. Kepegawaian

14. Kamar operasi

15. Dan lain-lain

Setelah sumber data rekam medis yang didapat, kemudiandata rekam medis tersebut dapat diolah atau diproses untuk penghitungan statistik berdasarkan indikator-indikator pelayanaan kesehatan untuk menghasilkan suatu informasi kesehatan yang efektif dan akurat. Selanjutnya informasi tersebut dapat digunakan oleh pihak intern rumah sakit dan pihak ekstern. Adapun pihak-pihak yang memanfaatkan data rekam medis antara lain:

Pihak Intern RS:

1. Direktur

2. Wadir

3. Kabag/kabid

4. Ka instalasi

5. Ka subag/kasi

6. Kaur

7. Medis, paramedis 
8. Non medis

Pihak Ekstern RS

1. Depkes RI

2. Dinkes propinsi

3. Dinkes Kab/kota

4. Pelkes dasar dan rujukan

5. Pemilik rumah sakit (bupati/walikota/yayasan)

6. Pemasok obat $\&$ alkes

\subsection{Sumber Data Statistik Rumah Sakit}

Sumber data statistik rumah sakit dihasilkan dari data rekam medis yang ada di Unit Rekam Medis di rumah sakit. Adapun sumber data yang dihasilkan dari unit rekam medis antara lain di:

- Tempat Penerimaan Pasien Rawat Jalan /TPPRJ

1. Register pendaftaran rawat jalan

2. KIUP

- Unit rawat jalan/URJ

1. Register pasien Rawat Jalan

2. Sensus Harian Rawat Jalan

3. Register/catatan tindakan pelayanan

4. Rekapitulasi bulanan rawat jalan

- Unit gawat darurat/UGD

1. Register pasien $\mathrm{GD}$

2. Sensus harian GD

3. Register/catatan tindakan GD

- Tempat penerimaan pasien rawat inap/TPPRI

1. Buku register pendaftaran Rawat Inap

2. Catatan penggunaan tempat tidur

- Unit rawat inap URI

1. Sensus Harian Rawat Inap

2. Buku Register Pasien Rawat Inap 
3. Buku Register Persalinan \& Abortus

4. Buku Register Tindakan Med is

5. Rekapitulasi bulanan sensus Rawat inap

- Instalasi pemeriksaan penunjang/IPP

1. Register penerimaan Spesimen

2. Register Pemeriksaan penunjang

3. Sensus Harian Pemeriksaan Penunjang

- Assembling

1.Catatan penggunaanformulir RM

2.Kartu Kendali (KK)

- Filling

1 Buku catatan peminjaman dokumen RM

2 Tracer

- Koding/indeksing

1. Indeks Penyakit

2. Indeks Kematian

3. Indeks Operasi -

4. Indeks Dokter

5. Indeks Bayi.

6. Indeks Kebidanan

Berdasarkan macam data dan sumbernya, yakni data rutin dan data ad hoc. Data rutin adalah data yang dikumpulkan oleh Fasyankes dalam waktu yang berkala dan teratur. Data ad hoc merupakan data yang pengumpulannya dilakukan saat dibutuhkan dan tidak menentu. Survay merupakan contoh pengumpulan data secara ad hoc atau pada waktu tertentu.

Data sekunder digunakan jika data rutin maupun data ad hoc yang pengumpulan data nya diperoleh dari institusi lain. Sedangkan data primer merupakan data yang dikumpulkan murni dari seorang peneliti. Kesimpulannya adalah pembeda antara data sekunder dan data primer adalah sumber datanya. 
Data yang diperoleh melalui pengukuran pada satu subjek atau individu disebut sebagai data individu. Contohnya seperti pengukuran kadar hemoglobin, tinggi badan, biaya perawatan tiap pasien. Sementara itu data dapat pula diperoleh secara berkelompok atau yang dikenal sebagai data agregat, contoh data pasien infeksi nosokomial tiap bangsal perawatan, unitnya adalah bangsal perawatan yang terdiri dari berbagai pasien. Datapun dapat diperoleh dari pengukuran berulang (repeated measures) pada subjek yang sama, maka data yang diperoleh disebut sebagai data berpasangan atau dependen (paired data). Sebagai contoh data tekanan darah pasien sebelum diberi Obat. dan sesudah diberi Obat, pengetahuan pasien tentang HIV sebelum dan sesudah penyuluhan. Penyediaan informasi dengan pendekatan ilmiah dihafapkan memiliki keputusan yang objektif, walaupun kadangkala pendekatan berdasarkan keahlian juga sering dilakukan. Mendapatkan informasi selalu diawali oleh proses yang berawal dari data dan kemudian data tersebut harus dilakukan analisis dan penyajian data yang pada akhirnya akan didapati suatu informasi untuk mengambil keputusan.

Pada penyediaan informasi bila dilakukan secara terukur (dengan angka), maka dikatakan melalui pendekatan kuantitatif. Adapun prosedur untuk melakukan hal tersebut dikenal sebagai prosedur statistik, suatu prosedur yang dimulai dari pengumpulan data, pengolahan dan penyajian data, analisis serta penyimpulan.

Di Sisi lain ada pendekatan kualitatif, suatu pendekatan yang secara khusus memberikan teknik untuk memperoleh jawaban atau informasi mendalam tentang pendapat dan perasaan seseorang. Dengan penelitian kualitatif memungkinkan kita mendapatkan hal-hal yang tersirat (insight) 
mengenai sikap, kepercayaan, motivasi dan perilaku target populasi (Kresno, Sudarti, dkk, 2000). Sumber data untuk dalam statistik rumah sakit, yaitu:

\begin{tabular}{|ll|}
\hline \multicolumn{1}{c}{ Sumber data } & \multicolumn{2}{c|}{ Contoh } \\
\hline Data Primer & Rekam Medis \\
\hline Data Sekunder & Indeks penyakit, indeks \\
& operasi, indeks pasien, \\
dan berbagai indeks & lainnya \\
& - Hasil sensus pasien \\
& Aktifitas dalam unit \\
& kerja/unit pelayanan \\
\hline
\end{tabular}

Informasi, fakta, dan pengetahuan yang merupakan hasil dari aktivitas statistic Rumah sakit sangat dibutuhkan oleh berbagai pihak untuk berbagai kebutuhan, meliputi:

- Administrasi pelayanan

Pasien rawat jalan menggunakan statistik Kesehatan untuk mengetahui isu dalam staf pelayanan Kesehatan dan untuk membedakan jenis pelayanan. Contoh, jika jumlah pasien dalam ICU meningkat, manajemen administrasi Rumah sakit ingin melakukan penambahan jumlah tempat tidur dan pegawai untuk memenuhi kebutuhan. Manajemen quality control akan mengumpulkan data untuk membuktikan bahwa fasyankes memang memerlukan untuk dilakukan penambahan tempat tidur dan penambahan pegawai sesuai kebutuhan.

- Manajer departemen pelayanan Manajer departemen dapalam pelayanan Kesehatan yang menggunakan statistic untuk mencapai tujuannya. 
Seperti, seorang manajer yang ingin mengetahui apakah departemennya memiliki kondisi keuangan yang sesuai atau jika tidak, manajer tersebut akan melakukan penyelidikan.

- Unit pelaksana registrasi kanker

- Unit keperawatan

- Organisasi pelayanan Kesehatan lainnya

- Unit pengelola obat dan alkohol

- Peneliti pelayanan Kesehatan

- Lembaga Pendidikan dan penelitian Kesehatan

- Badan pengelola akreditasi dan,

- Pemerintah.

\subsection{Review Matematika dalam Statistik Pelayanan Kesehatan}

\section{a. Pecahan}

Pecahan adalah satu atau lebih bagian dari keseluruhan bagian. Gambar berikut menggambarkan mengenai pecahan.

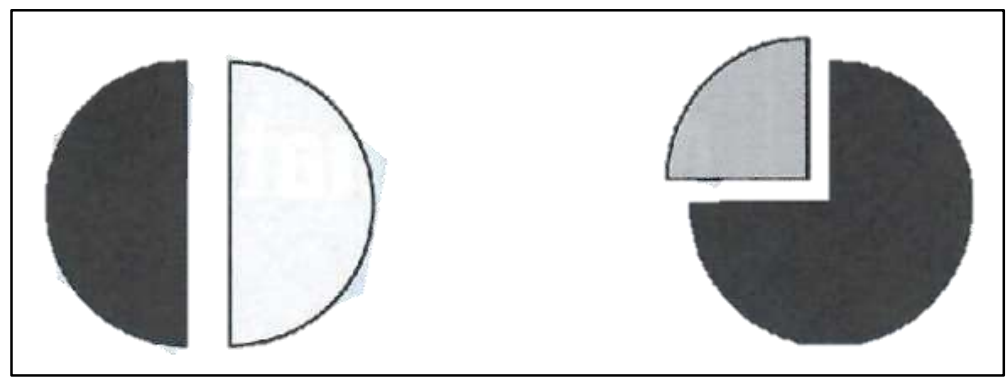

Gambar 1.1 Contoh Pecahan

Pada bulatan pertama merupakan gambar yang bulat yang dibagi menjadi dua sama besar sedangkan pada gamabr kedua ada salah satu bagian yang besar 
daripada bagian yang lainnya. Pecahan pada gambar pertama adalah $1 / 2$ sedangkan bulatan yang kedua dengan bagian yang gelap adalah $3 / 4$. Angka dibagian atas pada (1/2 atau $3 / 4)$ adalah numerator sedangkan angka yang dibawah adalah denominator.

Contoh:

Dari 40 pasien dengan diabetes mellitus yang berkunjung di klinik pada bulan lalu 20 orang adalah suku jawa dan 10 suku madura, 10 orang suku bugis. Pecahan berikut menunjukkan jumlah pasien yang dibandingkan dengan jumlah total pasien: 20/40 suku jawa, 10/40 suku madura, dan 10/40 suku bugis. Pecahan harus disederhanakan menjadi pecahan yang lebih sederhana seperti $20 / 40=2 / 4=1 / 2 ; 10 / 40=1 / 4$.

Dalam pecahan terdapat perhitungan sebagai berikut:

- Pembagian

Pembagian adalah jumlah yang dipilih dalam menentukan numerator yang dibagi dengan denominator. Angka ini akan menghasilkan decimal.

- Desimal

Pecahan decimal biasa disebut dengan decimal. Tanda menunjukkan nilai kurang dari 1. Contoh pada angka 14.37, digit pada angka 3 dan 7 disebut dengan digit decimal.

\section{b. Pembulatan}

Pembulatan merupakan bentuk upaya untuk pendekatan ke suatu posisi angka tertentu. 


\section{Pembulatan ke puluhan terdekat.}

Misalnya, angka 31 adalah angka yang terletak diantara 30 dan 40, namun angka ini posisinya lebih dekat ke angka 30. Jadi, dalam pembulatan ke 10 terdekat, angka 31 akan dibulatkan menjadi 30.

Angka 37 adalah angka yang terletak di antara 30 dan 40, namun angka ini posisinya lebih dekat ke angka 40. Jadi, dalam pembulatan ke 10 terdekat, angka 31 akan dibulatkan menjadi 40. Jika suatu angka terletak pas di tengah-tengah antara dua puluhan, maka aturan yang di ikuti adalah membu latkannya ke atas, $\mathrm{m}$ isalnya angka 35 akan dibulatkan menjadi 40.

\section{Pembulatan ke angka ratusan terdekat}

Misalnya angka 327 adalah angka yang terletak diantara 300 dan 400 tapi mendekati 300. Angka 27 mengindikasikan harus dibulatkan ke angka 300. Contoh lain adalah angka 376 maka di bulatkan ke angka 400.

\section{Pembulatan decimal}

- Setiap sarana pelayanan kesehatan bisa memiliki kebijakan sendiri tentang jumlah angka desimal yang digunakan dalam perhitungan dan pelaporan statistiknya.

- Sebagian besar angka statistik pelayanan kesehatan dilaporkan dalam bentuk desimal

- Jika angka pertama sesudah tanda koma desimal adalah angka yang kurang dari 5, gunakan angka bulatnya saja.

- Jika angka pertarna sesudah tanda koma desimal adalah angka yang lebih dari 5, bulatkan ke angka bulat-di atasnya. 
- Contoh: 14.4 dibulatkan menjadi 14 dan 17.6 dibulatkan menjadi 18.

- Aturan yang sama dapat digunakan untuk pembulatan ke satu angka di belakang desimal, misalnya 14.46 dibulatkan menjadi 14.5 dan 14.13 dibulatkan menjadi 14.1.

\section{c. Penghitungan Persentase}

Data dari analisa keluarnya pasien rawat inap berupa informasi dalam bentuk persentasi, angka, dan rasio. Persentase dihitung dengan hal keseluruhan dibagi menjadi 100. Data kurang dari dua puluh maka presentase tidak dapat digunakan. Oleh karena itu, beberapa persentase harus dihitung tiap tahun, bukan tiap bulan. Persentase bisa dihasilkan bila bagian pecahan dikonversi menjadi unit 100. Pecahan dua desimal (misal, 0,54) adalah bagian dari 100 , dan bisa dinyatakan sebagai persen (\%) dengan memindahkan titik desimal dua angka kekanan dan menambahkan tanda \% (54\%). Suatu persentase (misal, 24\%). Bisa dinyatakan dengan pecahan desimal $(0,24)$ dengan memindahkan titik desimal dua angka kekiri lalu tanda \% dihapus.

Pecahan $1 / 8$ mengasilkan 0,125. Bilangan 0,125 dapat dijadikan bentuk presentase jika dikalikan 100 lalu mengasilkan angka $12,5 \%$. Penambahan tanda \% dimaksud pengkalian hasil dengan angka 100 yang merupakan representasi pengubahan ke bentuk presentase. Pecahan 0,2 dikali 100 maka akan berubah menjadi 20, pengalian angka 100 disimbolkan dengan \%, Maka hasil dari 0,2 dikali 100 adalah $20 \%$. 
Rumah sakit harus membuat kebijakannya sendiri berapa titik desimal yang disepakati untuk pelaporan. Pembagian dilakukan harus lebih satu angka pada hasil bagi dibanding yang diinginan. Hasil bagi lalu dibulatkan ke angka yang diinginkan dengan menerapkan cara antara berikut: hilangkan angka terakhir jika angka tersebut kurang dari angka 5, tambahkan satu angka ke angka didepannya jika angka terakhir 5 atau lebih.

Istilah "rasio" sebagai ganti persentase. Sebuah rasio menyatakan hubungan kuantitatif satu hal dengan hal lainnya, seperti antara kematian dan kelahiran. Rasio ditulis sebagai perbandingan misal, 2:5 dibaca "dua banding lima", atau sebagai pecahan (2/5). Jadi rasio bisa dikurangi kepecahan desimal dari pecahan desimal ke persentase. Rasio bisa dinyatakan sebagai bagian dari 100 (persentase) dan sealiknya. Rasio 2:5 atau 2/5 adalah $40 \%$ hasil ini disebut tingkat.

Kehati-hatian harus diberikan pada persentase. Kesalahan menempatkan titik desimal merupakan kesalahan matematis yang banyak dialami. Perhitungan harus diperikas ulang untuk memastikan kebenarannya. Misalnya tingkat/angka kematian $45 \%$ nampak tidak mungkin. Dengan pengecekan ulang penempatan titik desimal, mungkin ditemukan bahwa angka tersebut seharusnya $4,5 \%$, atau bahkan $0,45 \%$.

Perbandingan persentase juga harus berhati-hati. Ilka persentase jumlah tertentu dikehendaki atau rasio antara jumlah total yang dibandingkan ditemukan, persentase harus dihitung pada jumlah total tertentu. Tidak benar menambahkan persentase.

Contoh:

\begin{tabular}{|l|l|l|l|l|}
\hline No. & Pelayanan & Jml & Jml Kematian & \% Kematian \\
\hline
\end{tabular}




\begin{tabular}{|r|l|r|r|l|}
\hline 1 & Pengobatan & 42 & 2 & 5 \\
\hline 2 & Bedah & 63 & 5 & 8 \\
\hline 3 & Kebidanan & 25 & 0 & 0 \\
\hline 4 & Melahirkan & 25 & 1 & 4 \\
\hline & Total & 155 & 8 & 5 \\
\hline
\end{tabular}

Jika persentase kematian dalam contoh di atas dijumlahkan, hasilnya menunjukkan persentase kematian $17 \%$. ang benar adalah 8 kematian dari 155 kasus adalah 5\%.

\section{d. Ratio}

Membandingkan jumlah sampel yang satu dengan yang lainnya. Misalkan dalam 1 minggu di RS X didapati 7 pasien berusia di atas 50 tahun dan 10 pasien lainnya di bawah sama dengan 50 tahun, maka dapat dikatakan rasio pasien berdasarkan umur di atas 50 tahun adalah 7: 10 atau dapat pula ditulis 7/10, Adapun total pasien adalah 17 pasien. Atau dari RS Y didapat dalam 1 tahun pasien rawat inap berjumlah 1000 sedangkan perawat berjumlah 100, maka rasio perawat terhadap pasien adalah 100: 1000

\section{e. Rate}

Merupakan ratio yang perbedaannya pada denominator atau penyebut yang berbasis populasi. Ukuran ini juga memiliki ukuran waktu. Fasilitas kesehatan dalam mengukur kinerja menggunakan rate untuk ukuran morbiditas dan mortalitas. Sebagai contoh: misalkan anda memiliki hobi menonton film di bioskop. Misalkan anda dalam 1 minggu ini menonton sebanyak 5 kali, padahal dalam 1 minggu umumnya menonton 14 kali, maka hitungan menonton dalam minggu tersebut adalah 5/14 atau 35,7\% atau rumusnya Rate $=$ Part $/$ base 


\section{f. Rerata}

Rerata adalah nilai yang didapatkan dari pembagian dari jumlah dari angka. Biasanya disimbolkan dengan $\mathrm{X}$ bar.

Untuk lebihi jelasnya silahkan lihat pada contoh berikut ini:

Ratio:

$$
\frac{x}{y}=\frac{5}{3}
$$

Proportion:

$$
\frac{x}{(x+y)}=\frac{5}{(5+3)}
$$

Percentage: $\quad\left[\frac{x}{(x+y)}\right] \times 100=\left[\frac{5}{(5+3)}\right] \times 100$

Rate:

$$
R=\frac{\text { Part }}{\text { Base }}, \text { or } R=\frac{P}{B}
$$

\section{Soal Latihan:}

\begin{tabular}{|c|c|c|}
\hline No & Tipe Data Pelayanan Kesehatan & Tipe Sumber Data \\
\hline 1. & $\begin{array}{l}\text { Laporan Hasil yang diambil dari } \\
\text { laporan kunjungan pasien. }\end{array}$ & (............. \\
\hline 2. & Tumor Registry & 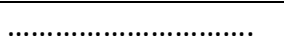 \\
\hline 3. & State Vital Statistic & ................................... \\
\hline 4. & Sensus RS & 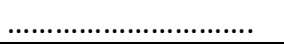 \\
\hline 5. & Rekam Medis pasien & 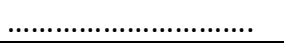 \\
\hline 6. & $\begin{array}{l}\text { Data Asuransi Kesehatan yang diambil } \\
\text { dari sensus nasional }\end{array}$ & 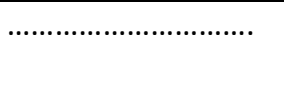 \\
\hline
\end{tabular}

1. Silahkan isi pada kolom yang kosong dengan "data primer" atau "data sekunder":

2. Potongan informasi yang menunjukkan kebenaran disebut:

a. fakta 

b. data
c. statistik
d. pengetahuan

3. Berikut ini yang termasuk sumber data primer adalah:
a. Kiup (Kartu Indeks Utama Pasien)
b. Kartu Katalog
c. Rekam Medis
d. Departemen Kesehatan

4. Informasi yang diperoleh dari pengolahan statustik Rumah sakit sangat dibutuhkan oleh:
a. Dokter
b. Pihak asuransi kesehatan
c. Manajemen rumah sakit
d. Semua jawaban benar

5. Berikut ini adalah contoh dari data agregat :
a. Tinggi badan seorang pasien
b. Data paslen infeksi nosokomial dari tiap bangsal di suatu rumah sakit
c. Suhu badan seorang pasien
d. Total biaya yang harus dibayar oleh seorang pasien

\section{Daftar Pustaka}


Ery Rustiyanto. (2010). Statistik rumah sakit untuk pengambilan keputusan. Graha IImu.

http://inlislite.dispusip.jakarta.go.id/dispusip/opac/d etail-opac?id=37915

Horton, L. A. (2017). Calculating and reporting healthcare statistics. /z-wcorg/. http://search.ebscohost.com/login.aspx?direct=true \&scope $=$ site $\& d b=$ lebk $\& d b=$ nlabk \&AN $=1404208$

Huffman, E. K., Cofer, J., Association, A. M. R., \& Association, A. H. I. M. (1994). Health Information Management. Physicians' Record Company. https://books.google.co.id/books?id=tmxrAAAAMAA J

Rano Indradi Sudra. (2010). Statistik rumah sakit: Dari sensus pasien, grafik Barber-Johnson hingga statistik kematian, otopsi, Perpustakaan Nasional RI. Graha Ilmu.

https://opac.perpusnas.go.id/DetailOpac.aspx?id=65 6174\#

Using health care data analytics to improve information management. (n.d.). SearchHealthIT. Retrieved September 18, 2020, from https://searchhealthit.techtarget.com/tutorial/Using -health-care-data-analytics-to-improve-informationmanagement 


\section{Tujuan Intruksional Umum}

Setelah mempelajari bagian ini, pembaca diharapkan mampu memahami pengertian sensus pasien beserta komponennya dan melakukan perhitungan berdasarkan hasil sensus data pasien.

\section{Tujuan Instruksional Khusus}

1. Memahami dan mampu menjelaskan mengenai perbedaan dan penerapan dari: pendafataran pasien rawat inap, sensus rawat inap, melengkapi form sensus pasien

2. Memahami pengertian ahri perawatan beserta perhitungannya

3. Memahami dan mampu melakukan perhitungan pasien transfer

4. Memahami dan mampu melakukan perhitungan pasien yang keluar dan masuk dihari yang sama

5. Melakukan rekapitulasi sensus

6. Menghitung rerata sensus pasien

\subsection{Pengertian Sensus Pasien}

Sensus pasien adalah kegiatan pengumpulan data jumlah pasien rawat inap yang dilakukan pelayanan pada waktu 1 × 24 jam yang dilaksanakan di rumah sakit terhitung dari jam 00:00 sampai jam 24:00 . Jumlah pasien yang dihitung termasuk jumlah pasien dipindahkan, pasien masuk dan pasien keluar dalam hal ini pasien maninggal maupun hidup. 
Jika pada sensus biasa (misalnya sensus penduduk) yang dihitung adalah jumlah yang saat ini (saat sensus) benar-benar ada (masih hidup), maka pada sensus harian rawat inap selain dihitung jumlah pasien yang masih ada di unit tersebut juga dihitung jumlah pasien yang masuk dan keluar pada hari yang sama dengan hari pelaksanaan sensus.

Kegiatan sensus dilakukan sesuai kebijakan rumah sakit masing-masing, namun idealnya sensus dilakukan mendekati jam 24.00 karena perhitungan 1 x 24 jam jumlah pasien rawat inap terlayani dalam suatu bangsal perawatan lebih mendekati valid. Pasien yang masuk dan keluar dihari yang sama termasuk dalam perhitungan sensus, walaupun kurang dari 24 jam. Jika hal ini tidak dilakukan maka pembayaran terhadap pelayanan Kesehatan pada pasien tersebut hilang dan terjadi kerugian dari pihak RS. Beberapa isu penting terkait sensus pasien meliputi:

- Satu unit dalam sastu pelayanan tidak bisanya dipisah atau dilaporkan dalam hari yang berbeda.

- Hari perawatan dihitung dalam sensus pasien namun discharge tidak

Jam tengah malam ditetapkan sebagai pelaksanaan sensus juga memiliki beberapa keuntungan antara lain:

- $\quad$ Tidak banyak pengunjung dan petugas lain sehingga suasana umumnya lebih tenang

- $\quad$ Tidak terlalu panas dan terkesan dingin suhunya sehingga umumnya lebih nyaman

- $\quad$ Tidak pada jam sibuk seperti jam kerja sehingga terkesan suasana umumnya lebih santai.

- $\quad$ Periode sensus akan lebih tepat dan mudah, karena tidak memotong hari.

Selain jumlah pasien yang masih dirawat, pelaporan sensus meliputi pasien-pasien dengan kritreria berikut : Pada periode sensus, jumlah pasien awal di unit tersebut. 
- Pasien baru dari rawat jalan

- Pasein Pindahan (Pasien dari ruang perawatan lain),

- Pasien keluar hidup maupun mati.

- Pasien keluar dan masuk pada hari yang sama.

- Pasien sisa atau pasien hari sebelumnya.

Bayi baru lahir termasuk dalam laporan perinatologi yang terpisah dari laporan sensus harian.

Berikut adalah contoh format dari rekapan sensus harian dari community manor nursing home: 
To be completed daily at 12:01 a,m.

ly charge nurse
Community Manor Nersing Home Daily Censas Sumanary

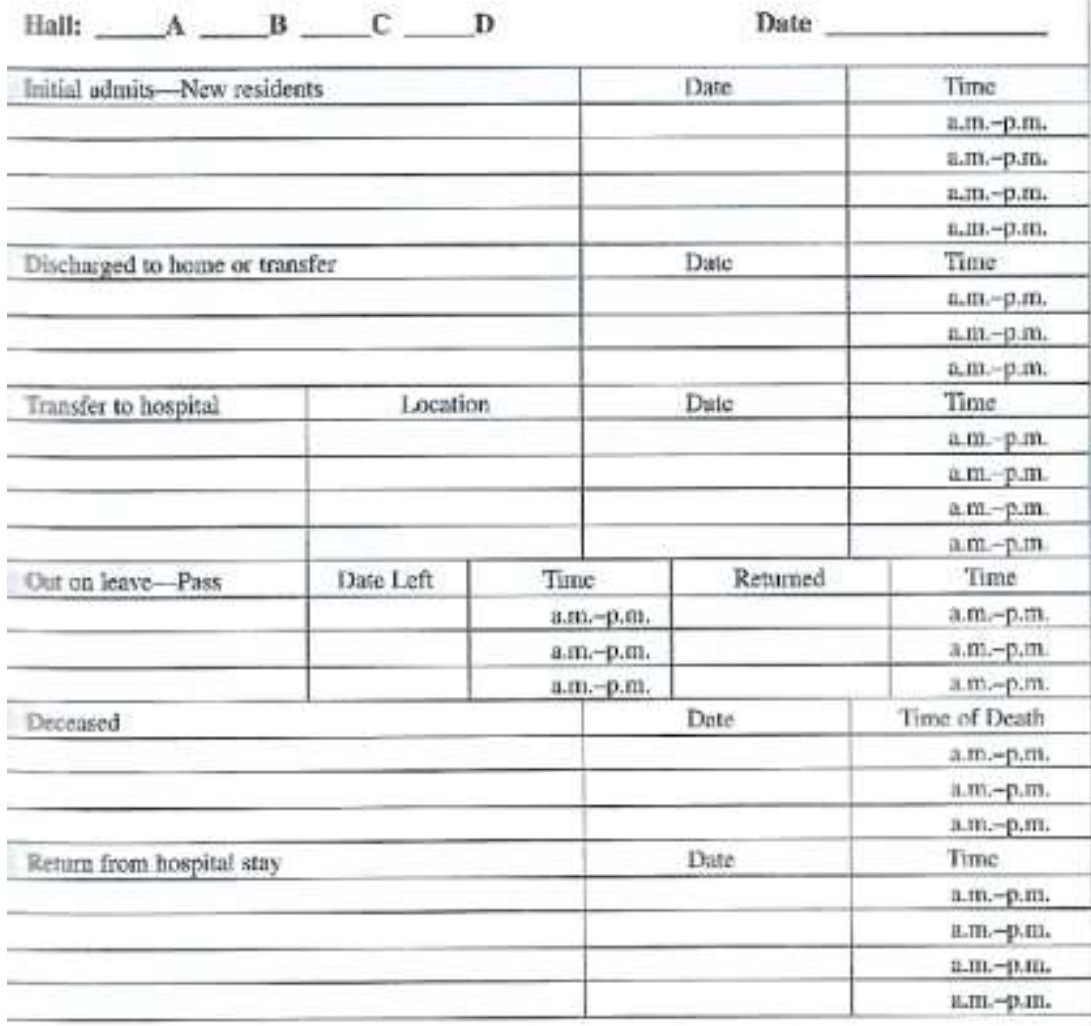

Charge aurse:

Hari Perawatan 
Hari Perawatan (HP = Inpatient bed day = bed day = patient day - inpatient service day)

Hari perawatan merupakan banyaknya beban kerja merawat pasien dalam kurun waktu tertentu. Jumlah pasien lama ditambah pasien baru ditambah jumlah pasien pindahan. Pasien pulang dan pasien dipindahkan termasuk dalam pasien lama pada saat sensus diambil.

Jumlah hari perawatan/total patient days/total inpatient service days

Jumlah hari perawatan dalam periode tertentu. Satu unit satuan dalam HP biasanya tidak memenggal periode hari penanggalan, jadi sesuai dengan periode hari penanggalan. Perhitungan HP hnaya menggunakan data pada saat tanggal masuk pasien, sedangkan tanggal keluar tidak diperhitungkan.

Contoh perhitungan HP:

Bulan: April 2008

\begin{tabular}{|c|c|c|c|c|c|c|c|c|c|c|c|c|c|c|c|c|c|c|c|c|}
\hline $\begin{array}{c}\text { Tgy } \\
\text { Pasilen }\end{array}$ & 1 & & & 5 & & & 10 & & & 15 & & & 20 & & & 25 & & & 30 & LD \\
\hline$A$ & & & & 0 & & & $\pi$ & & & & & & & & & & & & & 5 \\
\hline 8 & & & & & & & & & & $\infty x$ & & & & & & & & & & 1 \\
\hline C & & & & & & & 0 & & & L & & & $x$ & & & & & & & 10 \\
\hline D & & & & & & & & & & & & & & & & 0 & & & & \\
\hline$E$ & & & & $x$ & & & & & & & & & & & & & & & & 9 \\
\hline $\mathrm{Hi}_{\mathrm{i}}$ & 1 & 1 & 1 & 1 & 1 & 1 & 1 & 1 & 1 & 2 & 1 & 1 & 0 & 0 & 0 & 1 & 1 & 1 & 1 & \\
\hline
\end{tabular}

Keterangan:

Pasien A : masuk tgl.5 April dan keluar tgl.10 April

Pasien B : masuk tgl.15 April dan keluar tgl.15 April

Pasien C : masuk tgl.10 April dan keluar tgl.20 April

Pasien D : masuk tgl.25 April belum keluar hingga akhir April

Pasien E : masuk tgl.27 Maret keluar tgl.5 April

Total LD : $5+1+10+9=25$ hari $\rightarrow$ LD pasien D tidak dihitung karena belum keluar 
Total HP : $1+1+1+1+1+1+1+1+1+1+1+1+1+1+2+1+1+1+1$

$+.0+0+0+0+0+1+1+1+1+1+1=26$

Jumlah HP dihitung dengan cara menjumlahkan setiap HP (jumlah keseluruhan HP) dalam periode waktu tertentu. Misalnya jumlah HP dalam bulan bulan Januari didapatkan dengan cara:

HP tanggal $1+$ HP tanggal $2+$ HP tanggal $3+\ldots+$ HP tanggal 31 Januari.

\subsection{Pasien Transfer}

Pasien Transfer adalah pasien masuk dari bangsal unit rawat inap satu ke bangsal unit rawat inap lainnya di suatu rumah sakit. Jika ada bangsal perawatanmenerima pasien transfer (dalam sensus akan dihitung sebagai pasien pindahan) maka pasti ada bangsal yang telah mentransfer pasien tersebut (dalam sensus akan dihitung sebagai pasien dipindahkan). Data keluar masuknya pasien transfer antar bangsal menjadi alasan kuat penyeragaman penulisan sensus rawat inap dalam suatu rumah sakit agar tidak terjadi kesalahan pendataan.

Misalnya:

- Bangsal A melakukan sensus harian setiap jam 20.00 dan bangsal B setiap jam 23.00.

- Pada tanggal 5 jam 21.00, pasien Fulan dari bangsal A pindah ke bangsal B. Pada saat bangsal A melakukan sensus tanggal 5 tersebut (yaitu jam 20.00), Fulan masih tercatat sebagai pasien bangsal $A$. Pada saat bangsal $B$ melakukan sensus tanggal 5 tersebut (yaitu jam 23.00), Fulan juga sudah tercatat sebagai pasien di bangsal B. Dalam kasus ini maka Fulan -tercatat $2 x$ pada hasil sensus tanggal 5.

- Pada tanggal 7 jam 22.00, pasien Fulanah dari bangsal B pindah ke bangsal A. Pada saat bangsal A melakukan sensus 
tanggal 7 tersebut (yaitu jam 20.00), Fulanah BELUM tercatat sebagai pasien bangsal A. Pada saat bangsal B melakukan sensus tanggal 7 tersebut (yaitu jam 23.00), Fulanah sudah TIDAK tercatat sebagai pasien di bangsal B karena sudah dipindahkan ke bangsal A. Dalam kasus ini, pada tanggal 7 tersebut, Fulanah tidak tercatat sebagai pasien yang masih dirawat di bangsal A maupun di bangsal B. Tanggal 7 tersebut Fulanah HILANG dari daftar pasien rawat inap!

\subsection{Pasien Masuk dan Keluar pada Hari yang Sama}

Pasien dinyatakan dapat dinyatakan pelayanan rawat inap dan masuk dalam perhitungan sensus walau pasien hanya beberapa jam menempati ruang perawatan rawat inap dengan istilah pasien keluar dan masuk dihari yang sama.

Misalnya:

- Pasien Fulan masuk perawatan di bangsal A pada tanggal 5 Januari 2008 jam 09.00. Pada hari itu jam 15.00 Fulan meninggal. Pada saat bangsal A melaksanakan sensus hari itu (misalnya jam 23.00) maka Fulan akan tercatat sebagai pasien yang masuk dan keluar pada hari yang sama.

- Pasien Fulan masuk perawatan di bangsal A pada tanggal 5 Januari 2008.jam 09.00. Pada hari itu jam 15.00 Fulan pindah ke bangsal VIP. Pada saat bangsal A melaksanakan sensus hari itu (misalnya jam 23.00) maka Fulan TIDAK tercatat sebagai pasien yang masuk dan keluar pada hari yang sama, tetapi sebagai pasien dipindahkan (ke VIP).

- Pasien Fulan pindah dari bangsal VIP ke bangsal A pada tanggal 5 Januari 2008 jam 10.00. Pada hari itu jam 20.00 Fulan pindah dari bangsal A ke bangsal B. Pada saat bangsal A melaksanakan sensus hari itu (misalnya jam 23.00) maka Fulan TIDAK tercatat sebagai pasien yang masuk dan keluar 
pada hari yang sama, tetapi dicatat sebagai pasien pindahan (dari VIP) dan dipindahkan (ke bangsal B).

Seandainya pada hari itu Fulan meninggal di bangsal $A$ sebelum jam 23.00 WIB (jam pelaksanaan sensus bangsal A) maka Fulan tidak tercatat sebagai pasien yang masuk dan keluar pada hari yang sama, tetapi tercatat sebagai pasien pindahan (dari VIP) dan keluar (meninggal).

Pasien keluar dan masuk dihari yang sama termasuk dalam perhitungan lama dirawat (LD) atau rata-rata lama pasien dirawat (LOS) dihitung satu hari perawatan dan termasuk dalam perhitungan HP.

Kata kunci pada pasien masuk dan keluar pada hari yang sama adalah:

Sensus pada hari berikutnya harus dimulai pada pukul 23.59, dan merupakan sensus data bukan hari perawatan.

Perhitungan ini hanya untuk pasien yang terdaftar /masuk dan keluar pada hari yang sama dan buakn bayi baru lahir.

\subsection{Rekapitulasi Sensus}

Rekalitulasi sensus harian dalam suatu periode (misalnya satu bulan), adalah proses pengumpulan dan penggabungan data serta verifikasi kecocokan data setiap harinya.

Contoh, hasil akhir dari rekapitulasi sensus (misalnya bulan Januari 2008) di RS.XYZ, yaitu:

Sisa pasien (pada akhir Januari) jumlah pasien awal tanggal 1 Januari + semua pasien masuk dalam bulan Januari + semua pasien keluar (termasuk yang meninggal) dalam bulan januari. Jumlah sisa pasien ini harus sama dengan jumlah penghitungan 
langsung terhadap pasien yang masih dirawat pada malam sensus terakhir bulan Januari (actual head count). Jumlah sisa pasien bulan Januari ini akan menjadi jumlah pasien awal pada tanggal 1 Februari.

Untuk merekap sensus pada satu bangsal, misalnya rekapitulasi sensus bangsal Mawar RS.XYZ bulan Januari 2008:

Sisa pasien (pada akhir Januari) = jumlah pasien awal tanggal 1 Januari + semua pasien masuk dalam bulan Januari + semua pasien pindahan dari bangsal lain selama Januari - semua pasien yang dipindahkan ke bangsal lain selama Januari + semua pasien keluar (termasuk yang meninggal) dalam bulan januari.

Jumlah sisa pasien ini harus sama dengan jumlah penghitungan langsung terhadap pasien yang masih dirawat di bangsal tersebut pada malam sensus terakhir bulan Januari (actual head count).

Jumlah sisa pasien bulan Januari ini akan menjadi jumlah pasien awal bangsal yang bersangkutan pada tanggal 1 Februari. Berikut adalah contoh dari rekapitulasi sensus:

\begin{tabular}{|c|c|c|}
\hline \multicolumn{3}{|l|}{ Rumah sakit } \\
\hline & $\begin{array}{l}\text { Dewasa } \\
\text { dan anak- } \\
\text { anak }\end{array}$ & $\begin{array}{l}\text { Bayi } \\
\text { baru } \\
\text { lahir }\end{array}$ \\
\hline $\begin{array}{l}\text { Jumlah pasien di RS jam } 24.00 \text { pada } 1 \\
\text { oktober }\end{array}$ & 48 & 2 \\
\hline $\begin{array}{l}\text { Tambahan jumlah pasien masuk di bulan } \\
\text { oktober }\end{array}$ & $\begin{array}{l}100 \\
+\end{array}$ & $\begin{array}{l}7 \\
+\end{array}$ \\
\hline Subtotal & 148 & 9 \\
\hline $\begin{array}{l}\text { Dikurangi jumlah pasien keluar (termasuk } \\
\text { meninggal) dibulan oktober }\end{array}$ & 110 & $\begin{array}{l}5 \\
-\end{array}$ \\
\hline
\end{tabular}




\subsection{Rerata Sensus Pasien}

Rerata sensus harian menunjukkan rata-rata jumlah pasien yang dirawat setiap harinya dalam periode waktu tertentu. Rerata sensus harian dihitung dengan cara membagi total hari perawatan (HP, tidak termasuk bayi baru lahir) dengan jumlah hari dalam periode yang dimaksud.

Rumus:

$$
\text { Rerata sensus harian }=\frac{\text { total } H P(\text { tidak termasuk } B B L)}{\text { Jumlah hari dalam periode tertentu }}
$$

Contoh:

Dalam laporan 150 tempat tidur pasien, terdapat 3.489 hari perawatan selama bulan desember. Untuk menghitung rerata sensus pasien pada bulan desember, maka 3.489/31 (31 merupakan total jumlah hari bulan desember). 3.489/31=113. 113 adalah rerata sensus pasien bulan desember yang berarti terdapat 113 pasien yang berada dalam fasilitas pelayanan Kesehatan per hari di bulan desember.

Perhitungan ini penting dilakukan karena manajer dapat mengetahui berapa banyak pasien yag dilayani tiap bulan agar dapat menentukan kebutuhan pegawai dan kebutuhan suplly 
petugas medis dan untuk memonitor kinerja keuangan secara keseluruhan di fasilitas pelayanan Kesehatan.

\subsection{Rerata Sensus Bayi Baru Lahir}

Rerata sensus harian bayi baru lahir menunjukkan rata-rata jumlah bayi baru lahir yang dirawat setiap hari pada periode waktu tertentu.

Rerata sensus harian bayi dihitung dengan cara membagi total hari perawatan bayi baru lahir (HP bayi baru lahir) dengan jumlah hari dalam periode tertentu.

Rumus:

Rerata sensus harian $B B L=\frac{\text { total } H P B B L}{\text { Jumlah hari dalam periode tertentu }}$

Contoh:

Sebuah RS dengan TT bayi sebanyak 20 dengan jumlah hari perawatan BBL 552 selama bulan april. Maka rerata sensus harian BBL adalah 552/30 (30 adalah total jumlah hari di bulan april) = 18.4 atau 18 .

Tips:

Ketika administrator dan petugas medis bertanya tentang rerata sensus pasien, mereka tidak selalu mengindikasikan untuk meng-exclude (mengeluarkan perhitungan) bayi baru lahir (BBL). Klarifikasi informasi harus dilakukan apakah BBL masuk dalam laporan sensus atau tidak karena perhitungan berbeda. 


\subsection{Rerata Sensus Pasien ICU}

Petugas administrasi Kesehatan sangat terbantu dengan perhitungan rerata sensus pasien sehingga dapat mengetahui rerata penggunaan ICU (misalkan untuk mengetahui berapa jumlah kebutuhan TT ICU). Statistic adalah dasar dalam menentukan keputusan. Berikut adalah rumus yang digunakan dalam menghitung rerata sensus pasien ICU:

Rerata sensus pasien ICU $=\frac{\text { total HP pada unit ICU periode tertentu }}{\text { Jumlah hari dalam periode tertentu }}$

Contoh:

Sebuah RS dengan 24 TT di ICU melaporkan terdapat 740 hari perawatan di bulan juli. Untuk menghitung rerata sensus pasien ICU maka 740/31 (31 adalah total hari dibulan juli). Maka rerata sensus pasien ICU dibulan juli adalah 24.

Tips:

Jangan bingung dalam menentukan sensus dan hari perawatan. Hari perawatan mengindikasikan pasien saat ini pada waktu sensus. Beberapa pegawai RS hanya mengatakan "sensus" yang berarti sensus rawat inap. Rerata sensus pasien adalah jumlah pasien RS saat ini perhari pada periode tertentu. Hari perawatan termasuk pasien yang masuk dan keluar dihari yang sama.

\section{Soal-Soal:}

\section{Multiple Choice:}

1. Waktu dalam penentuan sensus pasien harus selalu:
a. Variabel
b. Konsisten
c. 24.00
d. 11.59 
2. Pasien sensus pada jam 12.01 adalah 24 . Kemudian 2 pasien masuk pada pukul 13.00. terdapat 1 pasien meninggal pada pukul 15.15 dan pasien lain keluar RS pada pukul 22.00 maka hari perawatan pada hari itu adalah:
a. 22
b. 24
c. 25
d. 26

\section{Essay:}

1. RS dengan jumlah TT sebanyak 200 dan 25 TT untuk BBL. Total hari perawatan selama bulan mei adaah 5.297 untuk dewasa\& anak-anak sedangkan 486 utuk BBL.

i. Hitung rerata sensus pasien untuk dewasa dan anakanak

ii. Hitung rerata sensus pasien $\mathrm{BBL}$

2. RS dengan $150 \mathrm{TT}$, dan $15 \mathrm{TT}$ untuk BBL. Hari perawatan untuk dewasa adalah 4.350 dan 360 untuk BBL selama bulan juni.

a. Hitung rerata sensus pasien untuk dewasa dan anakanak

b. Hitung rerata sensus pasien BBL

3. Hitung rerata sensus pasien BBL. RS memiliki TT 125 dan 10 TT BBL. Hari perawatan selama bulan februari adalah 3001 untuk dewasa dan 298 untuk BBL!.

4. Berikut adalah table hari perawatan pasien di sebuah RS ABC dengan 75 TT. Berapakah jumlah total hari perawatan pada bulan juni pada table tersebut? 


\begin{tabular}{|c|c|c|c|c|c|}
\hline Date & \multirow{2}{*}{$\begin{array}{c}\text { Inputient } \\
\text { Service Dayss }\end{array}$} & Date & \multirow{2}{*}{$\begin{array}{c}\text { Inpatient } \\
\text { Service Days }\end{array}$} & Date & \multirow{2}{*}{$\begin{array}{c}\text { Inpatient } \\
\text { Service Duys }\end{array}$} \\
\hline June & & June & & June & \\
\hline 1 & 70 & 11 & 68 & 21 & 68 \\
\hline 2 & 71 & 12 & 67 & 22 & 71 \\
\hline 3 & 72 & 13 & 65 & 23 & 70 \\
\hline 4 & 68 & 14 & 69 & 24 & 73 \\
\hline 5 & 69 & 15 & 70 & 25 & 70 \\
\hline 6 & 71 & 16 & 72 & 26 & 69 \\
\hline 7 & 73 & 17 & 73 & 27 & 67 \\
\hline 8 & 74 & 18 & 75 & 28 & 65 \\
\hline 9 & 69 & 19 & 70 & 29 & 69 \\
\hline 10 & 70 & 20 & 69 & 30 & 72 \\
\hline
\end{tabular}

5. Berapakah sensus pada tanggal 2 dan 3 juni?

\begin{tabular}{|c|c|c|c|c|c|c|c|c|c|c|c|c|c|c|c|}
\hline \multirow[b]{2}{*}{ Duy } & \multicolumn{2}{|c|}{$\begin{array}{l}12 y 01 \mathrm{zan} \text {. } \\
\text { Ceanas }\end{array}$} & \multirow{2}{*}{$\frac{\text { Adim }}{\text { AMC }}$} & \multirow[b]{2}{*}{ Bit } & \multirow{2}{*}{$\frac{\mathrm{TH}}{\mathrm{in}}$} & \multicolumn{2}{|c|}{ Total } & \multirow{2}{*}{$\frac{D i s}{M C}$} & \multirow{2}{*}{$\frac{\text { Dis }}{\text { NII }}$} & \multirow{2}{*}{$\frac{\text { Tif }}{\text { ant }}$} & \multicolumn{2}{|c|}{$\begin{array}{l}\text { Its9 p.th. } \\
\text { Census }\end{array}$} & \multirow[b]{2}{*}{ A/D } & \multicolumn{2}{|c|}{$\begin{array}{l}\text { Bery } \\
\text { Days }\end{array}$} \\
\hline & $\mathrm{AC}$ & $\mathrm{NB}$ & & & & $A C$ & NH & & & & $A N C$ & NII & & A/C & $\mathrm{NB}$ \\
\hline 6) & 48 & 1 & 2 & 1 & 1 & 51 & 3 & 1 & 2 & 1 & 49 & 1 & 1 & $\$ 0$ & 1 \\
\hline 62 & 49 & 1 & 3 & 1 & 2. & 54 & 2 & 4 & 1 & 2 & 48 & 1 & 1 & & \\
\hline $6 / 3$ & & & 1 & 1 & 1 & & & 3 & 0 & 1 & & & 0 & & \\
\hline
\end{tabular}

6. Berdasarkan informasi sejak 1 juni, pada tabel berikut lengkapilah kolom yang kosong!

\begin{tabular}{|c|c|c|c|c|c|c|c|c|c|c|c|c|c|c|c|}
\hline \multirow[b]{2}{*}{ Bay: } & \multicolumn{2}{|c|}{$\begin{array}{l}\text { 32:01 s.m. } \\
\text { Cenuss }\end{array}$} & \multirow{2}{*}{$\frac{\text { Altm }}{N C}$} & \multirow[b]{2}{*}{ Bir } & \multirow{2}{*}{$\frac{\text { Trf }}{\text { in }}$} & \multicolumn{2}{|c|}{ Total } & \multirow{2}{*}{$\frac{D i s}{A C}$} & \multirow{2}{*}{$\frac{\text { Din }}{\text { NII }}$} & \multirow{2}{*}{$\frac{\text { Trf }}{\text { out }}$} & \multicolumn{2}{|c|}{$\begin{array}{c}11-99 \text { p.m. } \\
\text { Censen }\end{array}$} & \multirow[b]{2}{*}{$\mathbf{A D}$} & \multicolumn{2}{|c|}{$\begin{array}{l}\text { Serv } \\
\text { Doys: }\end{array}$} \\
\hline & $A C$ & Nn & & & & MC & NB & & & & $\mathbf{M} / \mathrm{C}$ & NB & & $\mathrm{A} / \mathrm{C}$ & $\mathrm{NB}$ \\
\hline 611 & 230 & 12 & 20 & 4. & 3 & & & 19 & 3 & 2 & & & 1 & & \\
\hline $6 / 2$ & & & 21 & 4 & 1 & & & 19 & 4 & 1 & & & 0 & & \\
\hline $6 \sqrt{3}$ & & & 23 & 6 & 0 & & & 24 & 5 & 0 & & & 3 & & \\
\hline $6 / 4$ & & & 25 & 5 & 1 & & & 23 & 4 & 1 & & & 1 & & \\
\hline 65 & & & 24 & 4 & 2 & & & 18 & 3 & 2 & & & 2 & & \\
\hline
\end{tabular}




\section{Daftar Pustaka:}

Ery Rustiyanto. (2010). Statistik rumah sakit untuk pengambilan keputusan. Graha IImu. http://inlislite.dispusip.jakarta.go.id/dispusip/opac/d etail-opac?id=37915

Horton, L. A. (2017). Calculating and reporting healthcare statistics. /z-wcorg/. http://search.ebscohost.com/login.aspx?direct=true \&scope $=$ site $\& d b=$ nlebk $\& d b=$ nlabk $\& A N=1404208$

Huffman, E. K., Cofer, J., Association, A. M. R., \& Association, A. H. I. M. (1994). Health Information Management. Physicians' Record Company. https://books.google.co.id/books?id=tmxrAAAAMAA J

Rano Indradi Sudra. (2010). Statistik rumah sakit: Dari sensus pasien, grafik Barber-Johnson hingga statistik kematian, otopsi, Perpustakaan Nasional RI. Graha 
IImu.

https://opac.perpusnas.go.id/DetailOpac.aspx?id=65

6174\# 


\section{Tujuan Intruksional Umum}

Setelah mempelajari bagian ini, pembaca diharapkan mampu memahami pengertian mengenai penggunaan tempat tidur, persentase hunian tempat tidur, menghitung parameter efisiensi tempat tidur di RS.

\section{Tujuan Instruksional Khusus}

1. Mengidentifikasi tempat tidur yang termasuk dalam perhitungan jumlah tempat tidur RS

2. Menghitung jumlah tempat tidur yang terisi

3. Menghitung persentase penggunaan tempat tidur

4. Menghitung bed occupancy ratio (BOR)

5. Menghitung Length of Stay (LOS)

6. Menghitung turn over interval (TOI)

7. Menghitung bed turn over (BTO)

Perhitungan tingkat efisiensi rumah sakit merupakan salah satu aktivitas rutin yang dilakukan dalam statistika rumah sakit. Fungsi perhitungan tersebut adalah menghitung tingkat efisiensi penggunaan tempat tidur yang dapat digunakan untuk patikan evaluasi dan perencanaan di unit perawatan rawat inap.

Perencanaan jumlah tempat tidur digunakan manajemen rumah sakit untuk penyediaan tempat tidur rawat inap yang dapat menampung lebih banyak pasien sehingga dapat menghasilkan pemasukan dari pasien rawat inap. 
Dari aspek ekonomi, tentu pihak manajemen menginginkan agar setiap TT yang telah disediakan selalu terisi dan digunakan oleh pasien. Jumlah $\Pi \mathrm{T}$ yang kosong atau "menganggur" diharapkan sesedikit mungkin. Semakin lama seorang pasien menempati sebuah TT maka akan semakin banyak menghasilkan uang.

Dari aspek medis terjadi arah penilaian yang bisa berlawanan. Tim medis akan lebih senang dan merasa berhasil kerjanya jika seorang pasien bisa segera sembuh sehingga tidak perlu lama dirawat, jadi tidak menggunakan TT terlalu lama.

Berdasarkan latar belakang aspek medis dan ekonomi oyang bertolak belakang. Dibutuhkan kriteria atau menentukan apakah TT yang tersedia telah bermafaat dengan efisien. Parameter yang digunakan untuk memantau efisiensi penggunaan TT ini telah dirumuskan dan terdiri dari 4 parameter, yaitu:

1. Bed occupancy ratio (BOR);

2. Length of stay (LOS);

3. Turn over interval (TOI); dan

4. Bed turn over (BTO).

\subsection{Jumlah Tempat Tidur}

\section{Tempat Tidur yang Tersedia/Available beds/Bed count/Bed}

\section{Complement}

Jumlah tempat tidur yang tersedia jumlah tempat tidur di unit perawatan rawat inap yang ada dan siap digunakan sewaktu-waktu dalam perwatan pasien rawat inap baik yang sedang digunakan maupun tidak digunakan. Jumlah tempat tidur yang digunakan pasa saat darurat tidak termasuk dalam katagori jumlah tempat tidur yang tersedia. Tempat tidur bayi baru lahir tidak termasuk dalam perhitungan jumlah tempat 
tidur yang tersedia. Jumlah tempat Itidur yang tersedia biasanya disimbolkan dalam huruf $A$.

\section{Tempat Tidur yang Terpakai/Occupancy beds}

Tempat tidur yang terpakai adalah jumlah tempat tidur yang sedang digunakan untuk merawat pasien rawat inap yang sifatnya tidak darurat, dan bukan tergolong untuk pasien bayi baru lahir. Tempat tidur yang tidak terpakai namun tersedia untuk perawatan tidak termasuk dalam perhitungan tempat tidur yang terpakai atau istilah Occupacy Beds. Perhitungan julah TT terpakai sama dengan HP pada satu periode hari sensus yang sama.

Rata-rata jumlah $\Pi$ tarpakai (disebut juga Occupied beds dan disimbolkan dengan huruf 0 ), dihitung dengan cara menjumlahkan TT tersedia pada setiap harinya selama suatu periode lalu dibagi dengan jumlah hari dalam periode tersebut. Jadi, misalnya rnenghitung rerata jumlah TT terpakai selama periode bulan januari dapat dilakukan dengan cara:

$$
\text { o periode januari }=\frac{\text { Jumlah } T T \text { terpakai pada } \operatorname{tgl} 1+\operatorname{tgl} 2+\operatorname{tgl} 3+. . t g l 31}{31}
$$

Dengan memperhatikan cara menghitung ini, maka dapat disimpulkan bahwa rerata jurnlah TT terpakai dalarn suatu periode sama dengan jumlah HP dalam periode tersebut dibagi dengan jumlah hari dalam periode yang bersangkutan $(\mathrm{t})$, atau:

$$
O=\frac{\text { Jumlah } H P}{t}
$$

\section{Perubahan jumlah $\mathrm{TT}$ yang tersedia}

Setiap ada perubahan jurnlah TT yang tersedia (bisa penambahan maupun pengurangan) maka perlu dicatat untuk 
keperluan penghitungan parameter efisiensi penggunaan TT nantinya.

Perubahan jurnlah TT tersedia yang dimaksudkan di sini adalah perubahan yang bersifat permanen. Jadi, perubahan jumlah TT yang hanya sementara waktu (misalpya karena kondisi darurat) tidak dihitung sebagai perubahan.

Pembahasan dan contoh lebih lanjut dari penghitungan efisiensi penggunaan TT dengan adanya perubahan TT akan dibahas bersama dengan topik BOR (Bed Occupancy Ratio).

\subsection{Bed Occupancy Ratio (BOR) Pengertian}

Bed Occupancy Ratio (BOR) adalah rata-rata pemakaian tempat tidur dalam waktu tertentu dan disajikan dalam bentuk persentase.

BOR sering disebut juga:

- Percent of Occupancy Occupancy

- Percent Occupancy Ratio

Perhitungan BOR yang berkaitan dengan bayi baru lahir akan dibuat secara terpisah. Apabila menggunakan data dari lembar laporan RL-1, maka jumlah HP diambil di baris sub total (yaitu baris sebelum ditambah perinatologi).

Periode penghitungan BOR dalam setiap rumah sakit berbedabeda tergantung kebijakan masing-masing rumah sakit.

\section{RUMUS BOR:}

BOR dihitung dengan cara membandingkan jumlah TT yang terpakai $(O)$ dari jumlah TT yang tersedia (A). Perbandingan ini ditunjukkan dalam bentuk persentase. 
Jadi, rumus untuk rnenghitung BOR yaitu:

$$
B O R=\frac{O}{A} \times 100 \%
$$

Untuk menghitung BOR dalam suatu periode tertentu, misalnya BOR untuk bulan Januari, maka pengembangan rumusnya menjadi:

$$
\text { BOR Januari }=\frac{O}{A} \times 100 \%
$$

Rerata TT terpakai dalam suatu periode (0) samadengan jumlah HP dalam periode tersebut dibagi dengan jumlah hari dalam periode yang bersangkutan $(\mathrm{t})$, atau:

$$
O=\frac{\text { jumlah } H P}{t}
$$

maka BOR untuk bulan Januari dapat pula dihitung:

$$
\text { BOR Januari }=\frac{\text { jumlah HP periode januari }}{A x t} \times 100 \%
$$

\section{BOR dengan perubahan jumlah TT}

Jika terjadi perubahan jumlah $T T$ dalam periode yang akan dihitung BORnya, maka dapat diguriakan rumus sebagai berikut:

$$
B O R=\frac{\text { jumlah HP periode tertentu }}{\text { (jumlah TT1xt1)+(jumlah TT2 } x \text { t } 2)+\cdots(\text { jumlah TTzxtz })} \times 100 \%
$$

Misalnya:

RS XYZ memiliki TT tersedia 50. Pada tanggal 25 Januari terjadi penambahan 5 TT. Hingga akhir Januari tercatat jumlah HP = 1250. Maka untuk menghitung BOR periode Januari yaitu: 


$$
\text { BOR januari }=\frac{1250}{(50 \times 24)+55 \times 7)} \times 100 \%=78,9
$$

berikut adalan table contoh BOR:

\begin{tabular}{|c|c|c|}
\hline \multicolumn{3}{|c|}{$\begin{array}{l}\text { Rommunits Huspital } \\
\text { Octoher MJXS }\end{array}$} \\
\hline $\begin{array}{l}\text { Patient Care } \\
\text { Enit/Bed Count }\end{array}$ & $\begin{array}{c}\text { Inpatieat } \\
\text { Servize Days }\end{array}$ & $\begin{array}{c}\text { Percentage ol Occupuancy } \\
\text { (Reunded to One Decimal Polnt) }\end{array}$ \\
\hline Methicine/24 beds & $\$ 87$ & $\frac{(587 \times 100)}{(24 \times 31)}=\frac{58,700}{744}=78.9 \%$ \\
\hline Surgeryil6 heds & 432 & $\frac{(432 \times 100)}{(16 \times 31)}=\frac{43.200}{496}=87.1 \%$ \\
\hline Pyychiatric/4 bods & 124 & $\frac{(124 \times 100)}{(4 \times 31)}=\frac{12,400}{124}=100.0 \%$ \\
\hline Otstetrios 6 beds & 169 & $\frac{(169 \times 100)}{(6 \times 31)}=\frac{16,900}{186}=90.9 \%$ \\
\hline Totaly 50 beds & 1,312 & $\frac{(1.312 \times 100)}{(50 \times 31)}=\frac{131,200}{1,550}=84.6 \%$ \\
\hline
\end{tabular}

\section{BOR UNTUK PERINATOLOGI}

Perhitungan BOR untuk bayi baru lahir sama denagn BOR pada umumnya. Pembedanya adalah sumber data yang digunakan berupa data bayi baru lahir. perinatologi (bassinet) dan jumlah HP adalah HP dari kelompok perinatologi.

\section{Nilai Ideal BOR}

Secara statistik semakin tinggi nilai BOR berarti semakin tinggi pula penggunaan TT yang ada untuk perawatan pasien. Namun kita perlu memperhatikan bahwa semakin banyak pasien yang dilayani berarti semakin sibuk dan semakin berat 
pula beban kerja petugas kesehatan pada unit tersebut. Akibatnya, pasien kurang diperhatikan kejadian infeksi nosikomial juga meningkat (infeksi nosokornial adalah infeksi yang didapat di rumah sakit). Kualitas kinerja tim medis menurun karena disebabkan oleg angka BOR yang terlalu tinggi selain itu kinerja tim medis terjadi penurunan, keselamatan pasien terabaiakan dan menyebabkan kepuasan pelayanan menurun.

Di sisi lain, semakin rendah BOR berarti semakin sedikit TT yang digunakan untuk merawat pasien dibandingkan dengan TT yang telah disediakan. Dengan kata lain, jumlah pasien yang sedikit ini bisa menimbulkan kesulitan pendapatan ekonomi bagi pihak rumah sakit.

Dengan memperhatikan hal-hal tersebut di atas maka perlu adanya suatu nilai ideal yang menyeimbangkan kualitas medis, kepuasan pasien, keselamatan pasien, dan aspek pendapatan ekonomi bagi pihak rumah sakit.

Nilai ideal untuk BOR yang disarankan adalah 75\% - 85\%.

\subsection{Lama Rawat/Length of Stay (LOS)}

Lama dirawat (LD) rata-rata lama dirawat pasien di suatu unit perawatan rawat inap rumah sakit sejak tercatat sebagai pasien rawat inap hingga pasien dinyatakan keluar dari rumah sakit. Pasien yang belum keluar dari rumah sakit belum dapat dihitung LDnya.

Rata-rata lama dirawat disebut juga Length of Stay (LOS)/days of stay/ inpatient days of stay/duration of inpatient hospitalization

Angka LD dibutuhkan oleh pihak rumah sakit untuk 
menghitung tingkat penggunaan sarana (utilization management) dan untuk kepentingan finansial (financial reports).

\section{Cara menghitung LD}

Lama dirawat (LD) dihitung dengan cara sebagai berikut:

Jika tanggal masuk dan keluar berada dalam bulan yang sama, maka LD dihitung dengan cara mengurangi tanggal pasien keluar perawatan dengan tanggal pasien masuk perawatan.

Contoh:

Jika pasien masuk tanggal 3 Januari dan keluar tanggal 12 Januari maka:

$\mathrm{LD}=12-3=9$ hari

Jika tanggal masuk dan keluar berada dalam bulan yang berbeda, maka LD dihitung dengan cara mengurangi tanggal terakhir bu lan masuk dengan tanggal masuk lalu ditambah dengan tanggal keluar. Jika ada bulan di antara bulan masuk dan bulan keluar, maka jumlah hari dari "bu lan antara" tersebut juga ditambahkan.

Contoh:

Jika pasien masuk tanggal 3 Januari dan keluar tanggal 12 Februari maka,

$L D=(31-3)+12=28+12=40$ hari

(31 adalah tanggal terakhir bu lan Januari, 3 adala:h tanggal masuk, dan 12 adalah tanggal keluar). 
Contoh:

Jika pasien masuk tanggal 3 Maret dan keluar tanggal 5 Mei maka:

$\mathrm{LD}=(31-3)+5+30=28+5+30=63$ hari

31 adalah tanggal terakhir bulan Maret, 3 adalah tanggal masuk, 5 adalah tanggal keluar, dan 30 adalah jumlah hari dalam bulan April sebagai "bulan antara")

Jika tanggal masuk sama dengan tanggal keluar dan pada bulan yang sama, maka LD dihitung sebagai 1 hari. Hal ini berlaku baik pasien keluar dalam keadaan hidup maupun mati.

Contoh:

Jika pasien masuk tanggal 5 Januari (misalnya jam 09.00) dan keluar tanggal 5 Januari (misalnya jam 18.00), maka LDnya adalah 1 hari.

Kadang-kadang digunakan cara yang berbeda untuk menghitung LD guna keperluan statistik dan LD guna keperluan finansial. Untuk keperluan finansial misalnya menghitung biaya perawatan pasien, pihak rumah sakit bisa jadi menerapkan prinsip perhitungan LD = (tanggal keluar -tanggal masuk $)+1$ hari. Beberapa rumah sakit menetapkan batas jam keluar pasien di mana apabila pasien keluar melewati jam batas tersebut maka LD akan ditambah 1. Dibutuhkan ketetapan pihak manajemen rumah sakit apabila menggunakan kebijakan yang berbeda dalam menghitung LD agar petugas tidak keliru dan tidak timbul kerugian bagi pihak-pihak terkait. 
Contoh perhitungan LOS

\begin{tabular}{|c|c|l|}
\hline $\begin{array}{c}\text { Date } \\
\text { Anitted }\end{array}$ & $\begin{array}{c}\text { Date } \\
\text { Diseharged }\end{array}$ & \multicolumn{1}{c}{ L.OS } \\
\hline 725 & $9 / 25$ & 1 day \\
\hline 25 & $9 / 26$ & 1 day $(9 / 26-9 / 25=1$ day $)$ \\
\hline 25 & $9 / 30$ & 5 days $(9 / 30-9 / 25=5$ days $)$ \\
\hline 25 & $10 / 4$ & 9 days $(5$ days in September +4 days in Octobet $=9$ days $)$ \\
\hline 25 & $11 / 4$ & $\begin{array}{l}40 \text { days }(5 \text { days in September }+31 \text { days in October }+4 \text { days } \\
\text { in November }=40 \text { days })\end{array}$ \\
\hline
\end{tabular}

\section{Jumlah LD}

Jumlah LD merupakan total LD dari setiap pasien dalam kelompok yang dihitung dalam periode waktu tertentu.

Misalnya, jumlah LD bangsal Mawar pada bulan Januari adalah jumlah LD dari setiap pasien di bangsal Mawar yang keluar pada bu lan Januari. Pasien yang pada akhir bulan Januari belum keluar, belum bisa dihitung LDnya.

Contoh:

Data berikut ini adalah catatan tanggal masuk dan keluar dari setiap pasien di bangsal Mawar dalam bulan Januari 


\begin{tabular}{|c|c|l|c|l|l|}
\hline Pasien & $\begin{array}{c}\text { Tanggal } \\
\text { masuk }\end{array}$ & $\begin{array}{c}\text { Tanggal } \\
\text { keluar }\end{array}$ & $\begin{array}{c}\text { LD } \\
\text { (hari) }\end{array}$ & \multicolumn{2}{|c|}{ Keterangan } \\
\hline A & 3 lanuari & 7 Januari & 4 & & \\
\hline B & 25 Desember & 5 lanuari - & 11 & \\
\hline C & 28 Januari & - & $\begin{array}{l}\text { samp akhir Januari belum } \\
\text { keluar }\end{array}$ \\
\hline D & 15 Januari & 15 & 1 & \multicolumn{2}{l}{} \\
\hline
\end{tabular}

Dari data tersebut di atas, maka jumlah LD bangsal Mawar bulan Januari yaitu $4+11+1=16$ hari.

\section{Average Length of Stay (ALOS)/Rerata LD}

Rerata LO merupakan rerata LO dari sekelompok pasien dalam periode tertentu. Misalnya, rerata LO bangsal Mawar pada bulan Januari menunjukkan rerata lamanya setiap pasien dirawat di bangsal Mawar dalam bulan Januari.

Rerata LD disebut juga sebagai average Length of Stay dan sering ditulis avLOS atau aLOS.

\section{Contoh:}

Jika disebutkan bahwa rerata LD di rumah sakit XYZ bulan Januari adalah 7 berarti bahwa dalam bulan Januari tersebut rata-rata setiap pasien di rumah sakit XYZ dirawat selama 7 hari.

\section{Rumus:}

Rerata LD dihitung dengan cara membagi jumlah LD dengan jumlah pasien keluar (hidup maupun mati).

Jadi, jika selama bulan Januari di bangsal Mawar tercatat, jumlah LD= 115 hari

jumlah pasien yang keluar (hidup rnaupun mati) dari bangsal Mawar = 20 orang, maka rerata LD bangsal Mawar bulan Januari dihitung dengan cara: $115 / 20=5,75$ hari 


\section{LD Panjang}

Kadang-kadang, ada pasien yang dirawat dengan LO yang relatif lebih lama bila dibandingkan dengan LO pasien yang lain di suatu unit perawatan. Hal ini bisa terjadi, rnisalnya bila kondisi sakitnya paslon berat; koma; banyak komplikasi; dan sebagainya.

Apapun penyebabnva, LD dari seorang pasien yang jauh lebih lama dari LD pasien Jainnya bisa "mengganggu" perhitungan statistik nantinya. Misalnya, adanya "LD. panjang" ini bisa menyebabkan rerata LD cenderung bergeser ke lebih lama. Kondisi ini tentu bisa menimbulkan persepsi yang berbeda pada saat kita mengartikan rerata LD yang seperti ini:

Contoh:

LD pasien $A=3$ hari

LD pasien $B=5$ hari

LD pasien $C=4$ hari

LD pasien $D=3$ hari

LD pasien $E=6$ hari

Maka rerata LD dari kelompok tersebut yaitu $(3+5+4+3+6) / 5$ $=21 / 5=4,2$ hari. Artinya, masing-masing pasien tersebut ratarata dirawat selama 4,2 hari.

Jika misalnya LD pasien B tersebut adalah 35 hari, maka rerata LD dari kelompok tersebut akan menjadi 10,2 hari. Artinya, masing-masing pasien tersebut rata-rata dirawat selama 10,2 hari. Jadi, "seolah-olah" rerata LD dari kelompok tersebut cukup panjang yaitu 10,2 hari. Padahal hanya ada satu pasien (yaitu pasien B) yang LDnya jauh lebih panjang (yaitu 35 hari) dibandingkan LD pasien yang lain.

Kondisi ini disebut distorsi rerata (distorted average)

Untuk mengatasi kondisi seperti ini kita bisa- melakukan 2 cara, yaitu: 
- Memberi catatan dalam laporan yang dibuat agar pembaca laporan tahu bahwa ada "LD panjang" yang harus diperhatikan khusus waktu membaca rerata LD.

- Tidak menggunakan rerata (mean) dalam melaporkan ukuran pemusatan LD tapi menggunakan nilai median. Dengan menggunakan nilai median, maka kondisi dalam ilustrasi di atas dihitung sebagai berikut:

LD pasien $A=3$ hari

LD pasien $B=35$ hari

LD pasien $C=4$ hari

LD pasien $D=3$ hari

LD pasien $\mathrm{E}=6$ hari

setelah diurutkan, data LD tersebut menjadi: 3, 3, 4, 6, 35

Jadi median dari data tersebut adalah 4 (sedangkan meannya adalah 10,2).

\section{Rerata LD BBL}

Rerata LD untuk kelompok bayi baru lahir dapat dihitung dengan rumus berikut ini:

$$
\frac{\text { Jumlah HP BBL }}{\text { Jumlah BBL yang keluar (hidp maupun mati) }}
$$

\section{Cuti Perawatan}

Beberapa rumah sakit mengijinkan pasien untuk cuti perawatan. Pasien cuti perawatan adalah pasien yang meninggalkan rumah sakit untuk sementara waktu (satu atau beberapa hari) dengan seijin dokter yang merawatnya. Ijin dari dokter ini untuk memastikan bahwa memang kondisi pasien memungkinkan untuk pulang sementara (misalnya saat hari raya) dan nanti kembali lagi ke rumah sakit untuk melanjutkan proses perawatannya. 
Pada pasien yang cuti perawatan, perhitungan LDnya dikurangi dengan jumlah hari cutinya.

Ketentuan tentang cuti perawatan ini harus dipastikan dengan ketentuan (kebijakan) dari manajemen rumah sakit yang bersangkutan.

\section{Nilai Ideal LD}

Dari aspek medis, semakin panjang LD (demikian juga dengan aLOS) maka bisa menunjukkan kinerja kualitas rnedis yang kurang baik karena pasien harus dirawat lebih lama (lama sembuhya).

Dari aspek ekonomis, semakin panjang LD (demikian juga dengan aLOS) berarti semakin tinggi biaya yang nantinya harus dibayar oleh pasien (dan diterima oleh rumah sakit).

Standar keseimbangan atau standar efisiensi nilai LOS yang ideal adalah 3 sampai 12 hari.

Berikut adalah beberapa kumpulan rumus untuk mempermudah dalam perhitungan:

\begin{tabular}{|c|c|c|}
\hline Indikator & Numerator & Denominator \\
\hline ALOS & $\begin{array}{l}\text { Total LOS pada } \\
\text { periode tertentu }\end{array}$ & $\begin{array}{l}\text { Jumlah total } \\
\text { Discharge termasuk } \\
\text { meninggal pada } \\
\text { periode tertentu }\end{array}$ \\
\hline $\begin{array}{l}\text { ALOS untuk } \\
\text { newborn }\end{array}$ & $\begin{array}{lr}\text { Total LOS } & \text { untuk } \\
\text { semua } & \text { BBL } \\
\text { discharges } & \text { dan }\end{array}$ & $\begin{array}{lr}\text { Jumlah } & \text { total } \\
\text { Discharge } \quad \mathrm{BBL} \\
\text { termasuk meninggal }\end{array}$ \\
\hline
\end{tabular}




\begin{tabular}{|l|l|l|}
\hline & $\begin{array}{l}\text { menninggal pada } \\
\text { periode tertentu }\end{array}$ & $\begin{array}{l}\text { pada periode } \\
\text { tertentu }\end{array}$ \\
\hline
\end{tabular}

\subsection{Turn Over Interval (TOI)}

Angka turn over interval (TOI) menunjukkan jumlah rata-rata tempat tidur tidak terpakai. Perhitungan hari dari mulai pasien pulang tidak menempati tempat tidur sampai tempat tidur diisi oleh pasien yang baru.

Rumus TOI:

TOI bisa digunakan rumus berikut ini:

$$
T O I=(A-O) \frac{t}{D}
$$

Dimana:

$A=$ jumlah TT tersedia

$0=$ rerata jumlah TT terpakai

$\mathrm{t}=$ jumlah hari dalam periode laporan

$\mathrm{D}=$ jumlah pasien keluar (hidup dan mati) dalam periode laporan

\section{Nilai Ideal TOI}

Semakin besar angka TOI, berarti semakin lama "menganggur"nya TT yakni semakin lama waktu tempat tidur tidak terpakai secara produktif. Tinggi nya nilai TOI mengakibatkan pihak rumah sakit tidak diuntungkan dari segi ekonomi

Semakin kecil angka TOI, berarti semakin singkat saat TT menunggu pasien barikutnya. Hal ini berarti TT bisa sangat produktif, apalagi, jika TOI=0 berarti TT tidak sempat kosong 1 
haripun dan segera digunakan lagi oleh pasien berikutnya. Hal ini bisa sangat menguntungkan secara ekonomi bagi pihak manajemen rumah sakit tapi bisa merugikan pasien karena TT tidak sempat disiapkan secara baik. Akibatnya, kejadian infkesi nosocomial mungkin bisa meningkat; beban kerja tim medis meningkat sehingga kepuasan dan keselamatan pasien terancam.

Berkaitan dengan pertibangan diatas, nilai TOI idealnya adalah antara 1-3 hari.

\subsection{Bed Turn Over (BTO)}

Angka bed turn over (BTO) menunjukkan frekuensi penggunaan setiap tempat tidur pada periode tertentu.

Misalnya didapatkan BTO bulan maret $=5$ pasien, maka berarti dalam bulan maret tersebut setiap TT yang tersedia rata-rata digunakan oleh 5 pasien secara bergantian.

Angka BTO ini sangat membantu kita untuk menilai tingkat penggunaan TT karena dalam dua periode bisa saja didapatkan angka BOR yang sama tapi BTOnya berbeda.

\section{Rumus BTO}

Untuk menghitung BTO bisa digunakan rumus berikut:

$$
B T O=\frac{D}{A}
$$

Ket:

$D=$ jumlah pasien keluar (hidup dan mati) dalam periode tertentu

$A=$ Jumlah TT tersedia dalam periode tertentu 
Contoh:

Di RS XYZ yang memiliki 50TT, selama bulan januari tercatat ada 355 pasien keluar (hidup maupun mati). Dair ilustrasi diatas, maka:

BTO $=\frac{D}{A}=\frac{355}{50}=7.1$ pasien

Artinya selama periode januari tersebut TT di RS XYZ rata-rata digunakan oleh 7,1 pasien secara bergantian.

\section{Nilai Ideal BTO}

Secara logika, semakin tinggi angka BTO berarti setiap TT yang tersedia digunakan oleh semakin banyak pasien secara bergantian. Hal ini tentu merupakan kondisi yang menguntungkan bagi pihak rumah sakti karena $\Pi T$ yang telah disediakan tidak "menganggur" atau praktis menghasilkan pemasukan.

Namun, bisa dibayangkan bila dalam 1 bulan 1 TT digunakan oleh 15 pasien, berarti rata-rata setiap pasien menempati TT selama 2 hari dan tidak ada hari dimana TT sempat kosong atau "menganggur". Ini berarti beban kerja tim perawatan sangat tinggi dan TT tidak sempat dibersihkan karena terus menerus digunakan pasien secara bergantian. Kondisi ini mudah menimbulkan ketidakpuasan pasien, bisa mengancam keselamatan pasien (patient safety), bisa menurunkan kinerja kualitas medis. Dan bisa meningkatan kejadian infeksi nosocomial karena TT tidak sempat dibersihkan atau disterilkan. 
Jadi, dibutuhkan angka BTO yang ideal dari aspek medis, pasien, dan manajemen rumah sakit.

Nilai ideal BTO yang disarankan yaitu minimal 30 pasien dalam periode 1 tahun. Artinya, 1 TT diharapkan digunakan oleh rata-rata 30 pasien dalam 1 tahun. Berarti 1 pasien rata- rata dirawat selarna 12 hari. Hal ini sejalan dengan nilai ideal aLOS yang disarankan yaitu 3-12 hari.

\section{Soal-Soal}

1. Hitunglah Persentase Hunian Tempat Tidur RS (BOR) pada table berikut:

\begin{tabular}{|l|c|l|}
\hline Tanggal & $\begin{array}{c}\text { Hari perawatan (inpatient } \\
\text { Service day) }\end{array}$ & BOR \\
\hline 1 & 75 & \\
\hline 2 & 77 & \\
\hline 3 & 72 & \\
\hline 4 & 79 & \\
\hline 5 & 73 & \\
\hline 6 & 74 & \\
\hline 7 & 76 & \\
\hline 8 & 60 & \\
\hline 9 & 69 & \\
\hline 10 & 54 & \\
\hline 11 & 59 & \\
\hline 12 & 63 & \\
\hline
\end{tabular}




\begin{tabular}{|l|c|l|}
\hline Tanggal & $\begin{array}{c}\text { Hari perawatan (inpatient } \\
\text { Service day) }\end{array}$ & BOR \\
\hline 13 & 65 & \\
\hline 14 & 66 & \\
\hline 15 & 67 & \\
\hline 16 & 56 & \\
\hline 17 & 71 & \\
\hline 18 & 78 & \\
\hline 19 & 57 & \\
\hline 20 & 52 & \\
\hline 21 & 53 & \\
\hline 22 & 50 & \\
\hline 23 & 55 & \\
\hline 24 & 58 & \\
\hline 25 & 68 & \\
\hline 26 & 64 & \\
\hline 27 & 80 & \\
\hline 28 & 70 & \\
\hline 29 & 62 & \\
\hline 30 & 61 & \\
\hline
\end{tabular}

2. Dengan menggunakan informasi pada table berikut, hitunglah BOR pada masing-masing unit RSA UMSIDA beserta total prosentase hunian tempat tidur.

\begin{tabular}{|l|l|l|l|}
\hline \multicolumn{4}{|c|}{ RSA UMSIDA } \\
\hline \multicolumn{1}{|c|}{ Unit } & Jumlah TT & HP & BOR \\
\hline Pediatric surgical & 30 & 833 & \\
\hline Hematology oncology & 20 & 566 & \\
\hline Neurosurgical & 30 & 756 & \\
\hline Endocrinology & 20 & 555 & \\
\hline Respiratory & 30 & 897 & \\
\hline Cardiac medicine & 20 & 589 & \\
\hline Infant care unit & 10 & 281 & \\
\hline Pediatric intensive care & 20 & 540 & \\
\hline Total & & & \\
\hline
\end{tabular}


3. Lakukan perhitungan LOS untuk pasien yang keluar dari acute care facility pada table berikut:

\begin{tabular}{|c|c|c|}
\hline Date Admitted & Date Discharged & LOS \\
\hline $7 / 9$ & $7 / 10$ & \\
\hline $9 / 12$ & $9 / 22$ & \\
\hline $3 / 10$ & $3 / 24$ & \\
\hline $6 / 17$ & $7 / 18$ & \\
\hline $10 / 20$ & $11 / 25$ & \\
\hline
\end{tabular}

4. Lakukan perhitungan LOS pada pasien yang keluar dari longterm facility pada table berikut:

\begin{tabular}{c|c|c}
\hline Dafe Admitted & Date Discharged & LOS \\
\hline $1 / 1 / 2009$ & $11 / 01 / 2014$ & \\
\hline $4 / 07 / 2012$ & $12 / 31 / 2013$ & \\
\hline $6 / 28 / 2011$ & $1 / 23 / 2012$ & \\
\hline $2 / 12012$ & $3 / 15 / 2013$ & \\
\hline $10 / 30 / 2013$ & $7 / 07 / 2014$ & \\
\hline
\end{tabular}

5. Hitunglah ALOS dan total ALOS pada table berikut: 


\begin{tabular}{|c|c|c|c|}
\hline \multicolumn{4}{|c|}{$\begin{array}{l}\text { Unitemity Vedical Center } \\
\text { Jamuary June, 21)XX }\end{array}$} \\
\hline Clinical Units & Discharges & $\begin{array}{l}\text { Discharge } \\
\text { Days }\end{array}$ & Alos \\
\hline Medicine & 12,280 & 61,400 & \\
\hline Surgery & 10,320 & 51,762 & \\
\hline Neurology & 12,464 & 68,320 & \\
\hline Oncology & 6,228 & 61,280 & \\
\hline Orthopedies & 4,906 & 20,624 & \\
\hline Rehabilitation & 1,926 & 48,250 & \\
\hline Urology & 678 & 2,698 & \\
\hline Psychiatry & 936 & 22,400 & \\
\hline Ophthalmology & 385 & 804 & \\
\hline Obstetries/Gynecology & 3,528 & 8,820 & \\
\hline Pediatrics & 3,148 & 18,388 & \\
\hline Total & & & \\
\hline
\end{tabular}

6. Hitunglah ALOS dan total ALOS pada bayi baru lahir pada table berikut: 


\begin{tabular}{|c|c|c|c|}
\hline & $\begin{array}{r}\text { Iinis } \\
\text { Annual Nont }\end{array}$ & $\begin{array}{l}\text { fil Hospital } \\
\text { Distharge Statiat } \\
\text { axx }\end{array}$ & \\
\hline Month & Nenborn Discharges & Dischrarge Days & Nenborn ALOS \\
\hline January & 100 & 278 & \\
\hline February & 128 & 427 & \\
\hline March & 107 & 247 & \\
\hline April & 148 & 300 & \\
\hline May & 152 & 327 & \\
\hline June & 143 & 396 & \\
\hline July & 162 & 422 & \\
\hline August & 163 & 433 & \\
\hline September & 183 & 568 & \\
\hline Octoher & 179 & 485 & \\
\hline November & 164 & 459 & \\
\hline December & 159 & 407 & \\
\hline Total & & & \\
\hline
\end{tabular}

7. Berapakah frekuensi penggunaan TT dengan sumber pemayaran menggunakan cash (biaya pribadi) pada table berikut:

\begin{tabular}{|c|c|c|}
\hline \multicolumn{3}{|c|}{$\begin{array}{c}\text { RS "Medika Utama" } \\
\text { Hari Perawatan dan Jumlah Pasien Keluar }(\mathrm{H}+\mathrm{M}) \text {, berdasarkan Sumber Pernbayaran } \\
\text { Juli-September } 2017(\mathrm{TT}=300)\end{array}$} \\
\hline Sumber Pembayaran & Hari Perawatan & Pasien Keluar $(\mathrm{H}+\mathrm{M})$ \\
\hline BPJS Kesehatan & 9.427 & 1.450 \\
\hline Asuransi Kesehatan lain & 5.340 & 802 \\
\hline Cash (Bayar Pribadi) & 13.604 & 2.011 \\
\hline Total & 34.533 & 5.058 \\
\hline
\end{tabular}

8. Hitunglah TOI pada periode bulan januari- maret 2017 pada table berikut: 


\begin{tabular}{|c|c|c|}
\hline \multicolumn{3}{|c|}{$\begin{array}{l}\text { Hari Perawatan dan Jumlah Pasien Keluar }(\mathrm{H}+\mathrm{M}) \text {, berdasarkan Pihak Pembayar } \\
\qquad \text { Januari-Maret } 2017\end{array}$} \\
\hline Pihak Pembayar & Hari Perawatan & Pasien Keluar $(\mathrm{H}+\mathrm{M})$ \\
\hline Tunai & 5.849 & 598 \\
\hline BPJS Kesehatan & 13.604 & 2.011 \\
\hline Asuransi kesehatan lain & 9.427 & 1.450 \\
\hline Kerjasama Perusahaan & 5.340 & 802 \\
\hline Total & 34.220 & 4.861 \\
\hline
\end{tabular}

\section{Daftar Pustaka}

Ery Rustiyanto. (2010). Statistik rumah sakit untuk pengambilan keputusan. Graha IImu. 
http://inlislite.dispusip.jakarta.go.id/dispusip/opac/d etail-opac?id=37915

Horton, L. A. (2017). Calculating and reporting healthcare statistics. /z-wcorg/. http://search.ebscohost.com/login.aspx?direct=true \&scope $=$ site $\& d b=$ lebk $\& d b=n l a b k \& A N=1404208$ Huffman, E. K., Cofer, J., Association, A. M. R., \& Association, A. H. I. M. (1994). Health Information Management. Physicians' Record Company. https://books.google.co.id/books?id=tmxrAAAAMAA $\mathrm{J}$

Rano Indradi Sudra. (2010). Statistik rumah sakit: Dari sensus pasien, grafik Barber-Johnson hingga statistik kematian, otopsi, Perpustakaan Nasional RI. Graha IImu.

https://opac.perpusnas.go.id/DetailOpac.aspx?id=65 6174\# 
BAB 4

GRAFIK BARBER JOHNSON

\section{Tujuan Instruksional Umum}

Setelah mempelajari bagian ini, pembaca diharapkan mampu memahami dan menginterpretasikan Grafik Barber Johnson.

\section{Tujuan Instruksional Khusus}

1. Membuat grafik barber johnson

2. Menginterpretasikan grafik barber johnson

\subsection{Pengertian Grafik Barber Jhonson}

Pada tahun 1973, Barry Barber, M.A., PhD., Finst P., AFIMA dan David Johnson, M.Sc berusaha merumuskan dan memadukan empat parameter untuk memantau dan menilai tingkat efisiensi penggunaan TT untuk unit perawatan pasien.

\subsection{Manfaat Grafik Barber Johnson}

Grafik BJ bisa dimanfaatkan untuk:

1. Menjadi pembanding tingkat efisiensi penggunaan tempat tidur dari suatu unit perawatan rawat inap dengan unit perawatan rawat inap lainnya dalam suatu rumah sakit untuk periode tertentu. 
2. Memantau perkembangan capaian target efisiensi dalam suatu periode tertentu.

3. Pemantauan dampak penerapan suatu kebijakan terhadap efisiensi penggunaan TT.

4. Memastikan kebenaran laporan efisiensi penggunaan TT dengan melihat titik perpotongan keempat garis bantu pada GBJ.

\subsection{Format Grafik Barber Johnson}

Grafik BJ memiliki format dasar sebagai berikut:

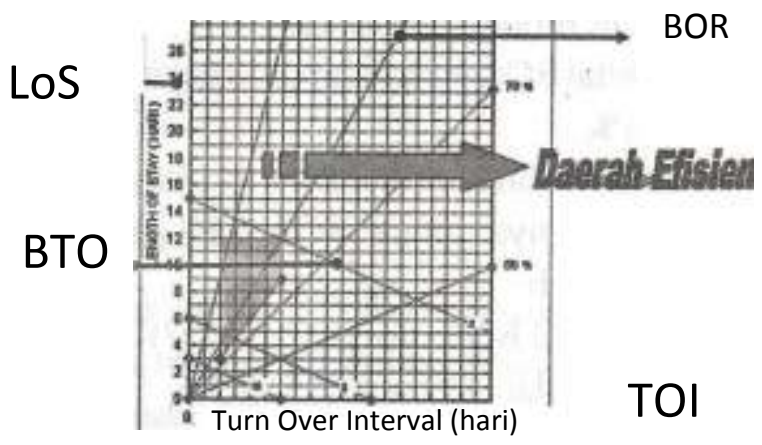

Terdapat judul yang secara jelas mencantumkan identitas RS dan/ atau bangsal yang dibuat grafik - BJnya serta periode laporannya.

Terdapat empat garis bantu yang dibentuk oleh empat parameter, yaitu

- TOI pada umumnya menjadi sumbu horisontal

- aLOS pada umumnya menjadi sumbu vertikal

- Garis bantu BOR merupakan garis yang ditarik dari pertemuan sum bu horisontal dan vertikal, yaitu titik 
0,0 dan membentuk seperti kipas

- Garis bantu BTO merupakan garis yang ditarik dan menghubungkan posisi nilai aLOS dan TOI. yang sama, misalnya garis yang menghubungkan aLOS=3 dengan TO1=3.

Terdapat area yang disebut "daerah efisien".

\subsection{Cara Membuat Grafik Barber Johnson}

Ketentuan-ketentuan yang harus diingat waktu membuat grafik BJ yaitu:

- Skala pada sumbu horisontal tidak harus sama dengan skala sumbu vertikal.

- Skala pada suatu sumbu harus konsisten.

- Skala pada sumbu horisontal dan vertikal dimulai dari angka 0 dan berhimpit membentuk koordinat 0,0.

- Judul grafik harus secara jelas menyebutkan nama RS, nama bangsal (bila perlu), dan periode waktu.

- Garis bantu BOR dibuat dengan cara:

- Tentukan nilai BORyangakan dibuatgaris bantunya, misalnya $\mathrm{BOR}=75 \%$

- Tentukan koordinat titik bantu BORnya sesuai nilai BOR tersebut, misalnya untuk BOR 75\% maka koordinat titik bantunya adalah:

LOS = nilai BOR dibagi $10=75 / 10=7,5$ dan TOI $=1$ nilai LOS $=1-7,5=2,5$

\{contoh lain, untuk membuat garis bantu BOR = $60 \%$ maka koordinat titik bantunya adalah LOS = 6 dan $\mathrm{TOI}=4$ ) 
- Tarik garis mulai dari koordinat 0,0 melewati titik bantu BOR tersebut

- Beri keterangan, misalnya bahwa garis tersebut adalah BOR $=75 \%$

- Garis bantu BTO dibuat dengan cara:

- Tentukan nilai BTO yang akan dibuat garis bantunya, misalnya BTO $=10$

- Tentukan titik bantu disumbu LOS dan TOI (nilainya sama) dengan cara:

titikbantu = (jumlah hari dalam periode laporan) dibagi (nilai BTO) $=30 / 10=3$ jadi lokasi titik bantunya adalah LOS = 3 dan TOI = 3 contoh lain, untuk membuat garis bantu BTO $=20$ untuk periode tribulan I maka titik bantunya adalah $\mathrm{LOS}=4,5$ dan $\mathrm{TOI}=4,5$. Angka 4,5 ini didapat dari $90 / 20$, di mana 90 adalah jumlah hari dalam periode tribulan I dan 20 adalah nilai BTO yang akan dibuat garis bantunya)

- Tarik garis yang menghubungkan kedua titik bantu tersebut

- Beri keterangan, misalnya bahwa garis tersebut adalah $\mathrm{BTO}=10$

- Daerah efisien dibuat dan merupakan daerah yang dibatasi oleh perpotongan garis:

- $\mathrm{TOI}=1$

- $\quad$ TOI $=3$

- $\quad$ BOR $=75 \%$

- $\quad$ LOS $=12$ 


\subsection{Cara Menggunakan Grafik Barber Johnson}

Setelah blangko grafik BJ dibuat sesuai ketentuan tersebut di atas maka kita bisa mulai menggunakannya untuk menilai efisiensi penggunaan TT di suatu RS atau bangsal pada periode tertentu dengan cara berikut ini:

- Siapkan data yang dibutuhkan untuk menghitung empat parameter (BOR, aLOS, TOI, dan BTO) untuk periode yang akan dibuat grafik BJ-nya. Periode grafik BJ bisa tahunan, semester, tribulan, atau bulanan. Data ini bisa diambil dari lembar laporan RL-1 periode yang bersangkutan atau dari lembar RP (rekapitulasi bulanan SHRI) atau sumber lainnya. Misalnya didapatkan data:

- Periode laporan adalah tahunan yaitu tahun 2002 (365 hari).

- $\quad$ Jumlah TT tersedia $=125$

- Jumlah HP = 36.500

- $\quad$ Rerata TT terpakai $=\mathrm{HP} / \mathrm{t}=36.500 / 365=100$

- Jumlah pasien keluar (hidup dan mati) $=2.500$

- Hitung nilai BOR, aLOS, TOI, dan BTO untuk periode tersebut (lihat bagian tentang cara nienghitung keempat parameter ini dalam buku ini), dari data tersebut di atas diperoleh hasil nilai:

- $\quad$ BOR $=80 \%$ aLOS $=14,6$ hari $\mathrm{TOI}=3,65$ hari $\mathrm{BTO}=20$ pasien

- Tentukan titik BJ dalam grafik BJ yang merupakan perpotongan dari keempat nilai parameter tersebut di atas dengan cara sebagai berikut:

- Tarik-garis bantu BOR $=80 \%$ 
- $\quad$ Tarik garis bantu aLOS $=14,6$

- $\quad$ Tarik garis bantu TOI $=3,65$

- $\quad$ Tarik garis bantu BTO $=20$

Jika perhitungan nilai keempat parameter tersebut benar (data, rumus, cara menghitung, pembulatan) keempat garis bantu itu akan berpotongan di satu titik. Titik itulah yang tadi disebutkan sebagai titik BJ.

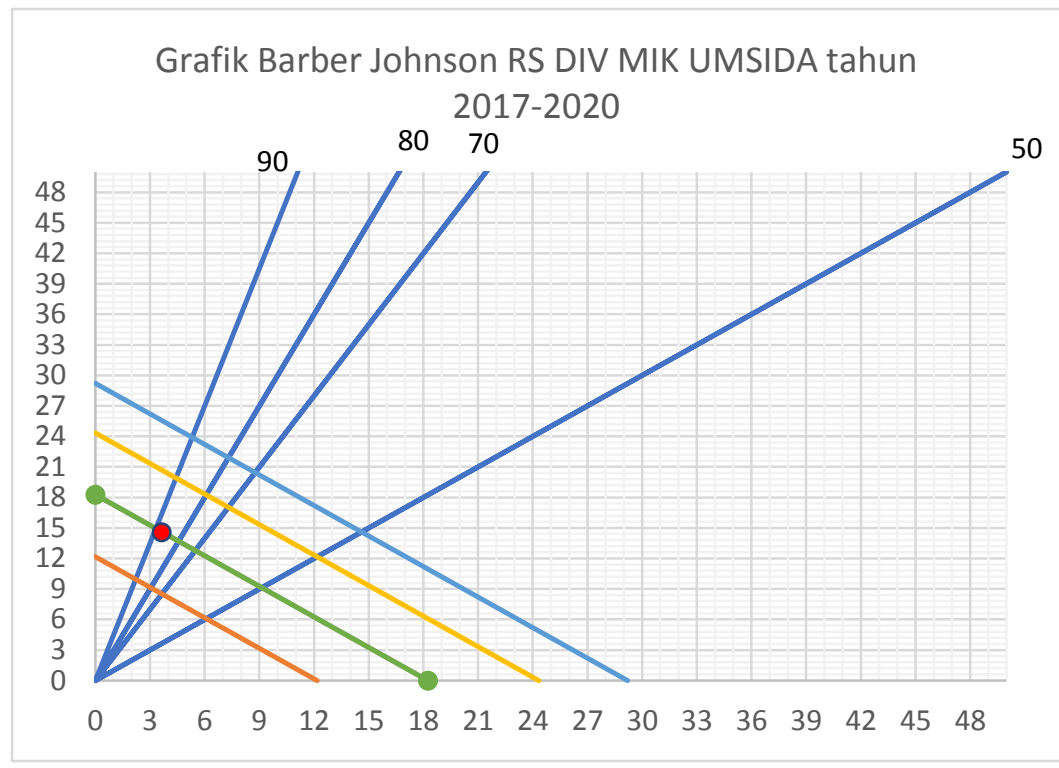

Untuk membaca grafik BJ, lihatlah posisi titik BJ terhadap daerah efisien. Apabila titik BJ terletak di dalam daerah efisien berarti penggunaan TT pada periode yang bersangkutan sudah efisien. Sebaliknya, apabila titik BJ masih berada di luar daerah efisien berarti penggunaan TT pada periode tersebut masih belum efisien.

\section{a. Makna Grafik barber Johnson}


1. Makin dekat grafik BOR dengan "Y" ordinat, maka BOR rnakin tinggi.

2. Makin dekat dengan grafik BTO dengan titik sumbu, discharges dan deaths per available (BTO) menunjukkan semakin tinggi jumlahnya.

3. Jika rata-rata TOI tetap, tetapi LOS berkurang, maka BOR akan menurun.

4. Bila TOI tinggi, kemungkinan disebabkan organisasi yang kurang baik, kurangnya permintaan akan tempat tidur atau kebutuhan tempat tidur, TOI tinggi dapat diturunkan dengan mengadakan perbaikan organisasi tanpa mempengaruhi LOS.

5. Bertambahnya LOS disebabkan karena keterlambatan administrasi di rumah sakit, kurang baiknya perencanaan dalam memberikan pelayanan kepada pasien atau kebijakan dibidang medis.

b. Kegunaan Grafik barber Johnson

1. Alat untuk membandingkan perkembangan pelayanan kesehatan rumah sakit dari tahun ke tahun yang dapat dilihat dari grafik ALOS, TOI, BOR dan bidang efisiensi.

2. Alat untuk menganalisa:

a. Mengetahui dengan cepat efisiensi suatu fasilitas kesehatan dengan melihat posisinya terhadap bidang (daerah) 
efisiensi, yaitu BOR $75 \%$, TOI minimal 1 hari clan Maksimal 3 hari

b. Membandingkan efisiensi suatu rumah sakit ffasilitas kesehatan yang satu dengan yang lain

3. Alat untuk menyajikan laporan rumah sakit

4. Alat untuk pengambilan keputusan

\subsection{Pengolahan data}

Pengolahan data yaitu suatu kegiatan untuk menyusun data yang di-peroleh seluruhnya menjadi suatu susunan yang dapat dianalisa dan ditarik kesimpulan. Pengolahan data dapat dilakukan dengan meng-gunakan tangan (manual) maupun mempergunakan alat elektronik, sehingga akan menghasilkan keluaran (output) yang dapat berbentuk tabel, grafik atau ringkasan seperti jumlah angka rata-rata, persentase dan sebagainya.

\section{Penyajian Data}

Data statistik seharusnya disajikan dengan cara yang mudah dicermati, menarik dan membuat data mudah untuk dipahami dan digunakan. Penyajian data terdiri dari tabel yang sederhana untuk mengerjakan grafik dengan teliti. dalam penyajian data di beberapa bentuk, penting untuk menjadi kesadaran dari pengguna laporan, tingkat kebenaranya dalam membaca dan menafsir data, dan ada atau tidak kepentingannya yang distimulasikan dengan grafik atau gambar penvaiian yang lain 


\section{- Tabel}

Penyajian data dalam bentuk grafik atau figura memerlukan sedikit penjelasan. Tabel adalah kolom di mana tiap kolom diberi label untuk mengidentifikasi isinya. label harus berjudul, bertanggal/waktu, dan ada identitas sumber data, bahkan ada peraturan yang mengatur tentang tabel distribusi frekuensi yang mana terdapat interval yang lebih baik dari angka-angka simple yang dimasukan ke dalam tiap-tiap kolom.

- Tabel Distribusi Frekuensi

Pengelompokan data ke dalam sejumlah kelas, dengan jumlah yang sesuai kedalam tiap-tiap kelas disusun tabel distribusi frekuensi

Contoh tabel distribusi Frekuensi

Tabel Frekuensi Distribusi

Distribusi Umur Pasien Masuk di RS X Bulan Januari 2008

\begin{tabular}{|c|l|c|}
\hline No. & \multicolumn{1}{|c|}{ Umur } & Jumlah Pasien Masuk \\
\hline 1 & Dibawah 16 & 98 \\
\hline 2 & $16-34$ & 34 \\
\hline 3 & $50-64$ & 107 \\
\hline 4 & 65 Keatas & 393 \\
\hline & Total & 870 \\
\hline
\end{tabular}




\section{- Grafik}

Penyajian data dengan grafik biasanya mempunyai kebaikan yang lebih daripada tabel daftar angka. Grafik dapat membantu pembaca memperoleh sebuah kesimpulan dari isi sajian yang cepat. Grafik harus menjadi sederhana dalam isi dan keterangannya (pembenaran label). Semua grafik harus berjudul ketika warna dan bayangan digunakan, sebuah kunci diperlukan, dan ketika lebih dari satu variabel ditunjukkan masing masing harus dibedakan dengan arti dari kunci.

Grafik dibuat dari kiri kekanan (sumbu horizontal) dan dari bawah ke atas (sumbu vertikal). Sepanjang sumbu horizontal (ditunjukkan sebagai sumbu $\mathrm{x}$ ) untuk mencatat variabel sumbu bebas (independent variable) yaitu beberapa faktor penyebab dibuatnya grafik. Itu mungkin kategori atau kelas-kelas data, misalnya hari dalam 1 minggu, unit tenaga kesehatan, DRG, dan sebagainya. Merekajuga menjadi interval atau angka tengah (middle) dari data, misalnya kelompok umur pasien atau jumlah hari perawatan. Bagian frekwensi ditempatkan disepanjang garis vertikal.

Garis vertikal (disebut sumbu y) itu digunakan untuk mencatat variabel terikat (dependent variabe/). Garis vertikal selalu dimulai dari nol.

Kesalahan menunjukkan total interval, bisa jadi ketika pada awalnya dimulai dari angka selain nol. Jika garis nol dihilangkan karena frekuensi terbanyak 
terdapat pada level teratas, pemakai seharusnya menandai itu dengan menggunakan sebuah rancangan yang biasanya _ ditunjukkan dengan sebuah unlighting merk"atau "tanda terang".

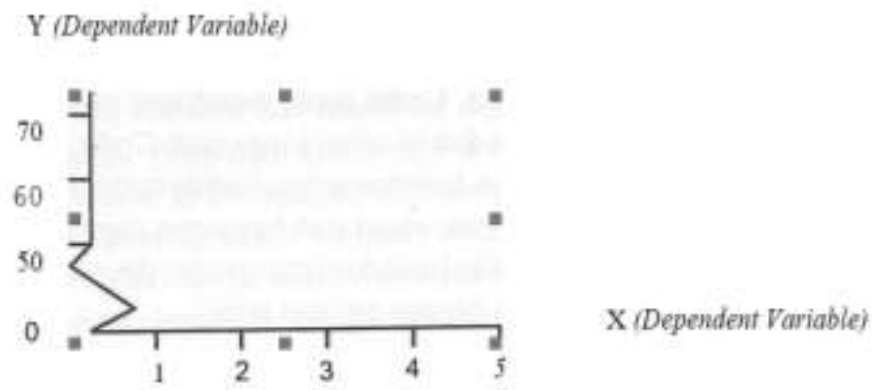

- Diagram Datang/Bar Graph

Diagram batang bentuk grafik yang paling sederhana, digunakan untuk menyajikan kategori data yang tidak berkelanjutan. 


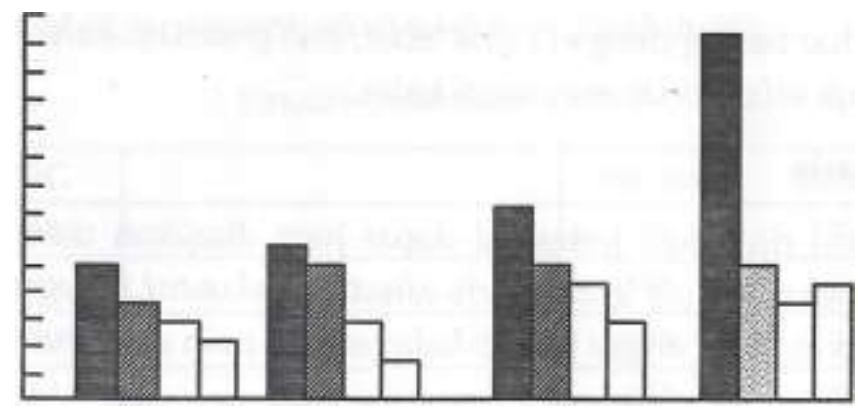

Gambar 4.1 Grafik Batang

\section{- Histogram}

Histogram adalah sebuah penyajian grafik dari distribusi frekuensi. Histogram dibangun dengan interval kelas yang mewakili pada sumbu horisontal, frekuensi kelas pada sumbu vertikal, dan digambar memanjang dari dasar kelas interval yang sama dan tingginya ditentu-kan oleh frekuensi kelas yang sesuai.

Berikut adalah contoh histogram dalam manajemen informasi Kesehatan: 


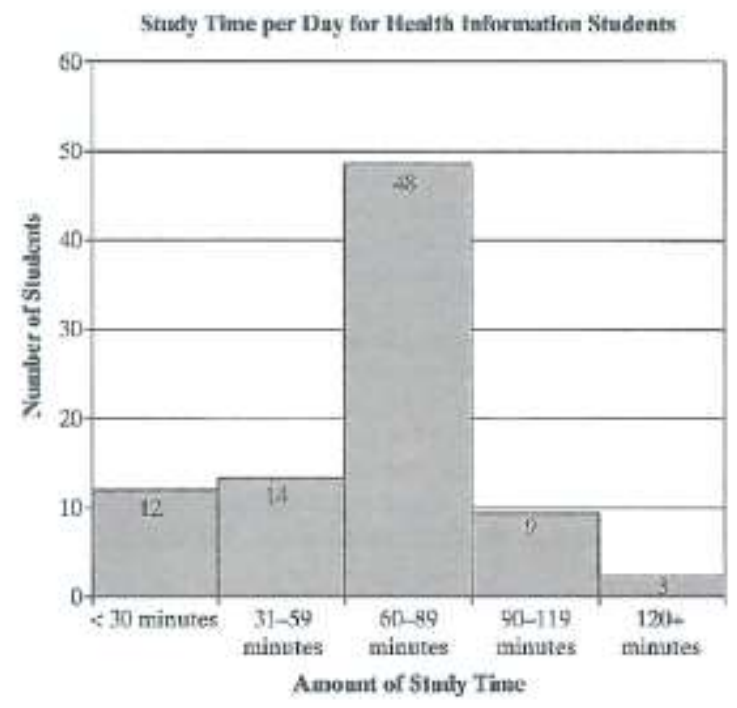

Gambar Histogram

Contoh grafik distribusi umum pasien masuk (tahun) di luar kelahiran Baru

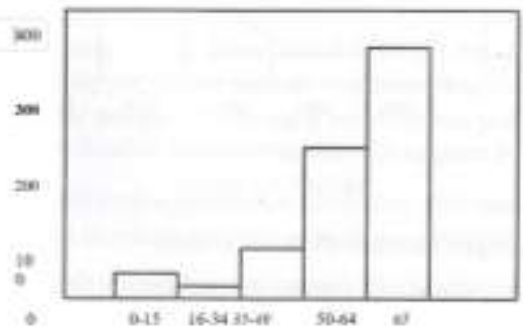

Gambar 4.2 Histogram 

$20 \mathrm{XX}$

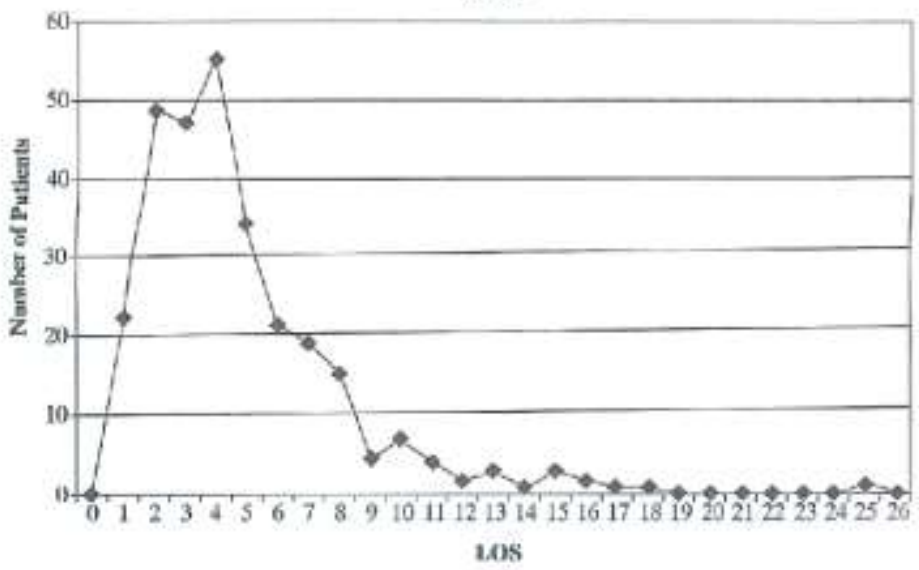

Gambar 4.3 Polygon 


\section{Soal-Soal}

1. Apa yang dimaksud aderah efisiensi pada grafik barber johnson? jelaskan!

2. Pada grafik barberjohnson, terdapat 4 titik pertemuan, iedealnya adalah berada pada daerah efisiensi. Apayang anda lakukan jika 4 titik tersebut bertemu diluar daerah efisiensi?

3. Sebutkan nilai ideal untuk BOR?

4. Berapakah nilai ideal untuk AvLOS agar titik pada grafik barber johnson berada daerah efisiensi?

5. RS MIK memiliki BTO 60 kali. Gambarlah titik BTO tersebut pada grafik barber johnson!

6. Gambarlah titik barber johnson jika Nilai BOR sebesar $75 \%$ !

7. Lakukan analisis terhadap Grafik berikut:

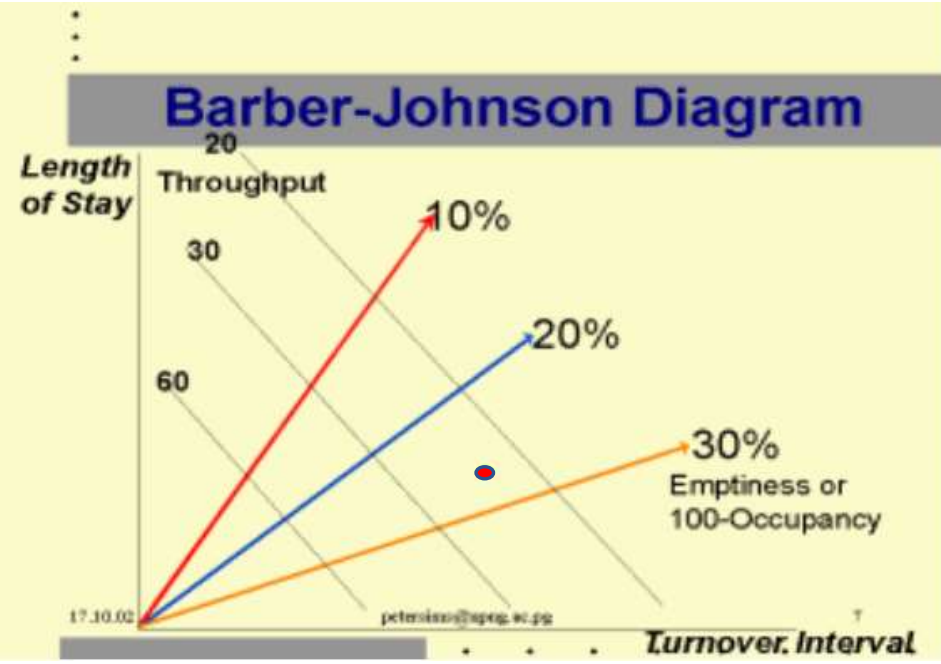

Daftar Pustaka 
Ery Rustiyanto. (2010). Statistik rumah sakit untuk pengambilan keputusan. Graha IImu. http://inlislite.dispusip.jakarta.go.id/dispusip/opac /detail-opac?id=37915

Horton, L. A. (2017). Calculating and reporting healthcare statistics. /z-wcorg/. http://search.ebscohost.com/login.aspx?direct=tru e\&scope $=$ site \&db=nlebk\&db=nlabk\&AN $=1404208$

Huffman, E. K., Cofer, J., Association, A. M. R., \& Association, A. H. I. M. (1994). Health Information Management. Physicians' Record Company. https://books.google.co.id/books?id=tmxrAAAAMA AJ

Kuzma J.W. 2005. Basic Statistic for Health Sciencies, Mayfield Publishing Company, California

Rano Indradi Sudra. (2010). Statistik rumah sakit: Dari sensus pasien, grafik Barber-Johnson hingga statistik kematian, otopsi, Perpustakaan Nasional RI. Graha IImu.

https://opac. perpusnas.go.id/DetailOpac.aspx?id= 656174\# 


\section{Tujuan Intruksional Umum}

Setelah mempelajari bagian ini, pembaca diharapkan mampu memahami dan menginterpretasikan statistic mortalitas di Rumah sakit.

\section{Tujuan Instruksional Khusus}

1. Memahami pengertian statistic mortalitas

2. Memahami Batasan-batasan dari pengolahan statistic mortalitas di Rumah Sakit

3. Menghitung GDR

4. Menghitung NDR

5. Menghitung postoperative death rate, anesthesia death rate, maternal death rate, newborn mortality rate, dan fetal death rate.

\subsection{Pengertian Statistik Mortalitas}

Angka kematian adalah informasi yang sangat penting di rumah akit dalam evaluasi kualitas pelayanan medis dan dapat digunakan untuk merencanakan pelayanan kesehatan yang akan datang.

Di Amerika Perubahan secara beraturan dan terkendali dalam Freedom of Information Act tahun 1985, sudah berkembang secara signifikan dari data rata-rata kematian. Garis pedoman Freedom of Information Act dibutuhkan peer Review 
Organizations (PROs) yang bekerja sama dengan Health Care Financing Administration (HCFIA) dari pemerintah Amerika untuk mengawasi kuatitas pelayanan medis yang menyediakan pelayanan medis untuk pasien. PROs menyediakan secara umum angka kematian spesifik rumah sakit dari jenis DRGs. Jumlah pasien yang dikirim karena operasi, infeksi, rata-rata lama rawat inap, dan biaya dan isi dari berbagai prosedur. Keluaran data adalah bagian dari strategi HCFIA untuk berkompetensi oleh dokter dan pelanggan dangan informasi lebih untuk menjamin pelayanan kesehatan yang tidak kurang tanpa menghargai kualitas pelayanan dan data dari PROs untuk dikembangkan melalui kemampuan pengawasannya.

Ketika pertama kali HCFIA "mortality data" dirilis dan banyak media yang tertarik dengan interprestasinya. Sejak itu kemudian muncullah modifikasi atau aturan-aturan pada mereka serta terdapatnya pengurangan pada suatu masalah, belum terjadi tantangan persen data untuk pelayanan kesehatan secara eksekutif dan informasi-informasi diringankan dengan bentukbentuk yang lebih sederhana. Arus data yang diterbitkan setiap tahun masuk untuk setiap pelayanan rumah sakit dan cara pelayanan kesehatan yang bermanfaat, prosentrase penerima ahli waris yang mati dalam 30 hari masuk, diharapkan prosentrase kematian dijumlah dalam dasar seluruh pengalaman dengan pasien yang sama, umur, jenis kelamin dan penyebab komplikasi penyakit di rumah sakit.

Rumah sakit seharusnya lebih menangkap dan mengumpulkan data dengan langkah perencanaan yang baik. Pertama merencanakan suatu hal untuk rumah sakit dan harusdilakukan peninjauan ulang pada pencatatan data rumah sakit tersebut. Perencanaan harus disampaikan sebelum dikeluarkan untuk masyarakat. Rumah sakit juga harus 
membandingkan antara data rumah sakit dan data kematian. Tekanan luar dan bentuk lain dari data yang disebarkan harus dikembangkan lebih lanjut menjadi data yang jelas. Sebagai contoh data Rumah sakit harus dianalisis untuk menentukan variable yang tidak dipertimbangkan oleh HCFA seperti pasien dengan "tidak ada kode" dan "tidak sadar" atau komplikasi lain.

Praktisi informasi kesehatan memahami dasar angka kematian dan staf diolah ke dalam data lain yang disinggung dalam angka kernatian yang mungkin diperlukan, dan kemudian data dikeluarkan dari HCFA.

\section{Kalkulasi Angka Kematian}

Macam-macam angka kematian yang mungkin bisa dikumpulkan mtara lain angka kematian kotor, angka kematian jaringan, angka kematlan sesudah operasi, angka kematian ibu, angka kematian bayi haru lahir, dan lain-lain.

Kematian dimasukkan ke dalam pelayanan karena kematian dideterminasi oleh pasien dalam rumah sakit. Angka kematian di rumah sakit didefinisikan ke dalam "glossarium of health care theme" sekarang proporsi pasien rumah sakit yang berakhir kematian, biasanya dinyatakan dalam persentase.

Pasien yang meninggal pada saat tiba Death on Arrival (DOA) tidak termasuk dalam angka ini. Pasien yang di ruang gawat di mana disana tanpa adanya suatu keputusan dan belum jelas penyediaan pelayanan kamar, papan, pelayanan perawatan yang berkelanjutkan dalam area rumah sakit di mana pasien umum tinggal bermalam dan tidak termasuk ke dalam angka ini, ketika seorang pasien mati maka akan disimpan dan dirawat di unit (ruang operasi, penyembuhan) dari rumah sakit lain ke unit gawat darurat pasien ini di pertimbangkan oleh rumah sakit. Janin yang mati tidak termasuk ke dalam angka kematian, jumlahnya harus 
dihitung secara terpisah dan jika pasien bayi baru lahir masuk dalam perhitungan, semua pasien bayi baru lahir masuk ke dalam angka kematian tersebut.

Angka kematian dikumpulkan sebelum dan sesudah 48 jam dari pendaftaran dan kadang-kadang diminta ke dalam laporan. Bagaimanapun juga sebagai indikator pelayanan rumah sakit seperti kejelasan adalah sangat diperlukan praktisi informasi kesehatan harus tahu data apa yang diminta kebentuk yang diminta untuk menentukan angka yang akan dikumpulkan secara reguler.

Contoh: sebuah rumah sakit mempunyai total angka kematian sejumlah 21 selama bulan mei, ini termasuk pasien mati semua umur, ini terjadi lebih dari 48 jam dan merupakan kasus jantung koroner atau kasus pemeriksaan medis totalnya 650 pasien yang termasuk angka kematian dalam sebulan. Angka kematian dirumuskan $21 \times 100$ dibagi 650=3,23\%. Jadi persentase angka kematian atau ratio angka kematian untuk bulan mei adalah 3,23\%. Beberapa rumah sakit akan dibulatkan paling dekat 10 dari $1 \%$ dan akan menjadi 3,2\%. Persentase pelaporan rumah sakit dalam hari ini akan menjadi $3 \%$.

Dari dasar angka kematian ini, jenis lain mungkin akan dihitung. Angka kematian sesudah operasi sering dikumpulkan dalam jumlah operasi dan ditunjukkan dalam 1 periode. Selain dikumpulkan beberapa rumah sakit lebih suka untuk memeriksa hubungan antara kematian dan operasi bedah seperti semua kematian yang di karenakan cholecysectomia.

Angka kematian untuk kandungan di sini disediakan komunitas kesehatan dengan informasi yang berharga pada kesehatan reproduksinya. Sebagai data yang menjadi trend di Amerika dan seluruh dunia. Angka ini banyak yang tidak dihitung secara rutin oleh rumah sakit swasta angka kematian terjadi 
berulang kali. Sayangnya data yang kosong mungkin disampaikan ke pihak luar yang menjumlah angka di Seluruh negara atau di negara bagian, wilayah, atau daerah setempat.

Untuk definisi kesehatan reproduksi "Glossary of Health Care Term" menerbitkan "Standard Terminology of Reproductive Health Statistic in The Us and Guidleness for Perinatal Care", standar terminologi disetujui oleh American College of Obstetri ang Gynerologist (ACOG) pada tahun 1985 dan dikembangkan untuk mempromosikan dan interprestasi reproduktif statistik kesehatan. The Guidliness for Perinatal Care dipublikasikan oleh ACOG tahun 1983.

Statistik kematian (mortalitas) adalah data yang menggambarkan perbandingan jumlah pasien yang meninggal rawat inap dalam suatu rumah sakit di suatu periode tertentu. Angka mrtalitas disajikan dalam bentuk presentase.

Angka kematian di rumah sakit disebut sebagai hospital death rate atau gross death rate.

Kegunaan dari statistika angka kematian RS adalah untuk mengevaluasi kualitas pelayanan dari sebuah rumah sakit. Selain itu, angka kematian dapat digunakan oleh peneliti dibidang kesehatan seperti mahasiswa rekam medis, pembiayaan kesehatan dan lainnya.

Dalam buku ini akan dibahas bentuk-bentuk dari statistik kematian di rumah sakit meliputi GDR, NDR, postoperative death rate, anesthesia death rate, maternal death rate, newborn mortality rate, dan fetal death rate. 


\subsection{Rumus dan Batasan dalam Menghitung Statistik Mortalitas}

Untuk menghitung statistik kematian rumah sakit dalam suatu periode, secara umum dapat menggunakan cara:

$\frac{\text { Jumlah pasien rawat inap yang mening gal(temasuk bayi baru lahir) }}{\text { Jumlah pasien yang keluar RS(hidup dan mati) }} \times 100 \%$

Jumlah pasien keluar merupakan jumlah pasien keluar mati dan keluar hidup. Perhitungan jumlahlah pasien meninggal apabila memasukkan bayi baru lahir meninggal, maka jumlah pasien keluarnya juga harus ditambah jumlah bayi keluar. Penambahan bayi baru lahir tergantung kebijakan setiap rumah sakit.

Jika kematian bayi baru lahir (newborn) dimasukkan sebagai bagian dari jumlah pasien yang meninggal (numerator) maka jumlah pasien keluar juga harus termasuk pasien bayi baru lahir (denominator). Umumnya, bayi baru lahir ikut dihitung dalam psnghltungan statistik kematian ini, kecuali ada ketentuan tersendiri dari manajernen rumah sakit yang ingin memisahkan hitungan kematian bayi baru lahir.

Pasien yang sudah meninggal saat dibawa dan rnasuk rurnah sakit (dead on arrival $=\mathrm{DOA}$ ) tidak ikut dihitung dalam statistik ini karena DOA tidak dianggap sebagai pasien rawat inap dan masuk dalam katagori pasien darurat, begitupun dengan pasien yang masuk dalam keadaan darurat meninggal saat masih di UGD.

Bayi yang lahir sudah dalam kondisi mati (fetal/ death) tidak ikut dihitung dalam statistik ini, tapi bisa dihitung secara tersendiri dan terpisah.

Angka hasil penghitungan statistik kematian disarankan untuk diekspresikan dalam dua tempat desimal karena angka statistik ini biasanya nilainya kecil. 
Sangat disarankan untuk menuliskan angka $\mathrm{O}$ di depan hasil penghitungan apabila hasil ini memang lebih kecil dari 1. Hal ini untuk lebih menegaskan bahwa memang angka yang didapatkan adalah lebih kecil dari 1. Jadi, lebih baik menuliskan 0,23\% daripada menuliskan hanya $23 \%$ saja walaupun maknanya secara matematika sama.

\subsection{Gross Death rate (GDR)}

Gross death rate (GDR) atau angka kematian kasar menunjukkan proporsi seluruh pasien rawat inap yang meninggal dalam periode waktu tertentu, termasuk bayi baru lahir (BBL) yang kemudian meninggal.

Untuk menghitung GDR digunakan rumus sebagai berikut:

$\frac{\text { Jumlah pasien rawat inap yang mening gal(temasuk bayi baru lahir)dalam periode tertentu }}{\text { Jumlah pasien yang keluar RS(hidup dan mati) }} \times 100 \%$

Contoh:

Jika dalam satu Rumah Sakit terdapat 7 pasien meninggal dan 520 Discharges dalam 1 bulan maka GDR nya adalah:

$$
\frac{7}{520} \times 100 \%=1.35 \%
$$

Konsep ini dapat di eksplore dengan lebih spesifik yang berarti rumusnya dinamakan dengan case fatality rate menjadi seperti berikut:

$$
\frac{\text { Jumlah orang meninggal dalam suatu periode }}{\text { Jumlah orang yang terkena penyakit }} \times 100 \%
$$


Case fatality rate adalah jumlah total psien meninggal dengan spesifik penyakit selama periode tertentu dibagi dengan jumlah total kasus selama periode tertentu. Missalnya pada kasus pasien acute mycardian infarction, setiap pasien discharge dengan diagnosis acute mycardian infarction memiliki potensial pasien meninggal. Jadi, rumus tersebut adalah:

Jumlah orang meninggal acute mycardian infarction Jumlah orang yang didiagnosis acute mycardian infarction $x 100 \%$

Jika sebuah RS terdapat 40 pasien dengan diagnosis acute mycardian infarction yang keluar RS (discharges) pada akhir tahun dan 8 meninggal maka death rate nya adalah:

$$
\frac{8}{40} \times 100 \%=20 \%
$$

\subsection{Net Death rate (NDR)}

Net death rate (NDR) adalah angka kematian pasien rawat inap yang perawatannya lebih dari 48 jam pada periode tertentu. Bayi baru lahir yang meninggal lebih atau sama dengan 48 jam termasuk dalam perhitungan NDR.

Nilai NDR menggambarkan pasien saat datang rawat inap ke rumah sakit tidak dalam kondisi sakit berat, sehingga rumah sakit memiliki cukup waktu untuk memberikan pelayanan terhadap pasien. 
Pasien yang meninggal kurang dari 48 jam menggambarkan kondisi pasien saat datag ke rumah sakit sudah cukup berat yang dapat diartikan meninggalnya pasien bukan karena mutu suatu rumah sakit buruk. Nilai NDR lebih memperlihatkan mutu pelayanan rumah sakit jika dibandingkan dengan GDR.

Untuk menghitung NDR dalam suatu periode digunakan rumus sebagai berikut:

$\frac{\text { Jumlah paslen (termasuk BBL)meninggal }-48 j a m \text { setelah perawatan }}{\text { Jumlah pasien keluar (termasuk yang mening gal dan BBL meninggal) - pasien meninggal }<48 \text { jam perawatan }} \times 100 \%$

Misalnya, sebuah RS melaporkan statistik rawat inap sbb:

- Jumlah total pasien meninggal : 5

- Jumlah pasien meninggal < 48 jam : 2

- Jumlah pasien pulang/keluar : 400

Maka NDR untuk periode tersebut adalah:

$$
N D R=\frac{5-2}{400-2} \times 100 \%=0.75 \%
$$

\subsection{Postoperative Death Rate}

Post operative date menggambarkan jumlah pasien meninggal setelah dilakukan tindakan operasi. Angka statistik ini merupakan rasio pasien yang meninggal dalam kurun waktu 10 hari setelah tindakan operasi terhadap jumlah total pasien yang dioperasi dalam periode tersebut.

Rumus:

Jumlah pasien yang mening gal dalam kurun waktu 10 hari pasca operasi dalam suatu periode Jumlah pasien yang dioperasi dalam periode tersebut

Contoh: 
Catatan statistik periode " $x$ " menyatakan ada 1000 pasien yang dioperasi dan 5 pasien meninggal pasca operasi ( 2 di antara nya meninggal dalam kurun waktu 10 hari pasca operasi), rnaka perhitungan postoperative death rate-nya adalah:

$$
\frac{2}{100} x 100 \%=0.2 \%
$$

\subsection{Anesthesia Death Rate}

Definisi dari anesthesia death rate adalah rasio kematian yang disebabkan oleh anesthetic agent (bahan-bahan kimia atau obatobatan dalam tindakan anestesi) selama kegiatan Tindakan anestesi pada periode tertentu. Karena kematian pada anestesi ini tidak begitu sering, maka beberapa RS memilih untuk mengevaluasi hubungan antara kematian dan tipe spesifik dari anestesi. Terdapat 3 tipe anestesi, yaitu:

1. General anesthesia: yaitu anestesi yangdiberikan secara intravena atau melalui inhaled.

2. Regional anestesi: yaitu anestesi Sebagian yang memungkinkan pasien masih sadar dan masih merasakan efek dari anestesi. Anestesi ini menghilangkan rasa pada bagian spesifik tertentu saja, misal pada tangan, lengan, kaki, atau wajah dan lain sebagainya.

3. Local anesthesi yaitu anestesi pada area yang sangat terbatas. Untuk rnenghitung anesthesia death rate digunakan rumus sebagai berikut:

Jumlah kematian karena anestesi dalam suatu periode

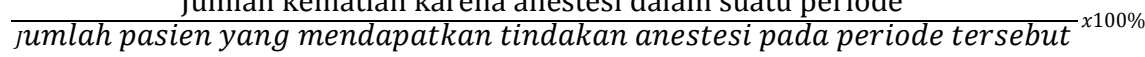

Contoh: 
RS MIK UMSIDA mencatat bahwa di antara 2000 pasien yang mendapat tindakan anestesi terdapat 1 pasien yang meninggal, maka anesthesia death rate-nya adalah:

$$
\frac{1}{2000} x 100 \%=0.08 \%
$$

\subsection{Maternal Death Rate}

Maternal death rate merupakan angka kejadian kematian dari seorang wanita yang sedang hamil atau dalarn kurun waktu 42 hari setelah penghentian kehamilan, tanpa melihat umur kehamilan dan lokasi kehamilan, dengan berbagai sebab yang berkaitan dengan kehamilannya atau pengelolaan kehamilannya, tetapi bukan karena kecelakaan atau penyebab incidental.

Contoh dari kematian akibat kecelakaan dapat termasuk di antara nya kecelakaan saat mengendarai sepeda motor atau misalnya jatuh dari tangga.

Contoh kejadian kematian insidental dapat meliputi pembunuhan atau bunuh diri.

Kematian ibu dapat dibedakan menjadi 2 kelompok, yaitu:

a. Kematian ibu karena faktor obstetrik secara langsung (direct obstetric deaths, Yaitu kematian ibu yang disebabkan karena komplikasi langsung dari kehamilannya (masa keharnilan; persalinan; dan nifas), dari intervensi terhadap kehamilannya, dari tindakan yang keliru, atau dari rangkaian hal-hal tersebut di atas. Misalnya, seorang pasien yang meninggal saat dilakukan operasi Caesar karena rusaknya arteri uterina yang menyebabkan perdarahan.

b. Kematian ibu karena faktor obstetrik tidak secara langsung (indirect obstetric deaths), Yaitu kematian ibu yang disebabkan 
karena penyakit terdahulu atau karena penyakit yang berkembang selarna masa keharnilannya dan. tidak secara langsung karena sebab obstetrik tapi berkaitan sebagal efek fisiologis dari kehamilan misalnya, pasien hamil dengan diabetes. Umumnya pihak RS hanya akan menghitung direct obstetric death sebagai angka maternal death dan yang dihitung hanya pasien yang memang meninggal sebagai pasien rawat inap.

Untuk menghitung maternal death rate digunakan rurnus sebagai berikut:

Jumlah maternal death dalam suatu periode

jumlah pasiem keluar obstetri (termasuk meninggal) pada periode tersebut

Dalam penghitungan ini, yang termasuk dihitung yaitu pasien prepartum not delivered dan pasien postpartum.

Prepeitum not delivered, yaitu kondisi sebelum kelahiran bayi, misalnya pasien yang datang ke RS untuk proses bersalin tapi belum sempat lahir bayinya pasien sudah keluar RS (bisa dalam kondisi hidup maupun meninggal).

Postpartum, yaitu kondisi setelah kelahiran bayi, misalnya pasien datang ke rumah sakit dengan kondisi infeksi pada luka bekas operasi Caesar.

Contoh perhitungan:

Selama tahun 2008, sebuah RB melaporkan bahwa jumlah pasien yang keluar ada 1.205. Di antara pasien yang keluar tersebut terdapat yang keluar dalam keadaan meninggal, yaitu:

- 2 orang meninggal setelah proses aborsi 
- 1 orang meninggal dengan cerebral hematoma karena kecelakaan lalu lintas

- 1 orang meninggal karena carcinoma uterina yang dipicu oleh kehamilan

Dari data tersebut di atas dapat dihitung maternal death rate-nya sebagai berikut:

$$
\frac{2}{1205} \times 100 \%=0.17 \%
$$

Dalam perhitungan diatas:

- Angka 2 menunjukkan jumlah pasien meninggal setelah proses aborsi (hal ini termasuk maternal death),

- Pasien yang meninggal dengan cerebral hematoma tidak ikut dihitung karena termasuk accidental death,

- Pasien dengan carcinoma uterina yang dipicu oleh kehamilan juga tidak dihitung karena dianggap sebagai indirect obstetric death.

\subsection{Newborn Death Rate}

Newborn death rate menggambarkan mengenai nilai yang informatif terkait Kesehatan reproduksi. Newbord death rate ini menyediakan data tren baik secara nasional maupun internasional.

Tipe dari kematian bayi dan definisinya dijelaskan dalam tabel berikut: 


\begin{tabular}{|l|l|}
\hline \multicolumn{1}{|c|}{ Tipe kematian } & \multicolumn{1}{|c|}{ Definisi } \\
\hline Newborn Death & $\begin{array}{l}\text { Kematian bayi lahir hidup di RS yang } \\
\text { meninggal selama di RS di hari yang sama }\end{array}$ \\
\hline Neonatal death & $\begin{array}{l}\text { Kematian bayi lahir hidup di RS kurang dari } \\
\text { periode neonatal (27 hari, 23 jam, dan 59 } \\
\text { menit) dari kelahiran }\end{array}$ \\
\hline $\begin{array}{l}\text { Postneonatal } \\
\text { death }\end{array}$ & $\begin{array}{l}\text { Kematian bayi lahir hidup di RS dari 28 hari } \\
\text { kelahiran ke akhir dari 1 tahun hidup (364 } \\
\text { hari, 23 jam, 59 menit) dari kelahiran }\end{array}$ \\
\hline Infant death & $\begin{array}{l}\text { Kematian bayi lahir hidup di RS kapan saja } \\
\text { selama sebelum 1 tahun (364 hari, 23 jam, } \\
\text { 59 menit) dari kelahiran }\end{array}$ \\
\hline Perinatal Death & $\begin{array}{l}\text { semua istilah inklusif yang mengacu pada } \\
\text { bayi lahir mati dan kematian neonatal }\end{array}$ \\
\hline
\end{tabular}

Berikut adalah rumus untuk menghitung newborn death rate:

Jumlah BBL dalam suatu periode

${ }_{\text {jumlah seluruh BBL yang keluar(termasuk mening gal) pada periode tersebut }}{ }^{x 100 \%}$

\subsection{Fetal Death Rate}

Fetal death (atau lahir mati) di Rumah Sakit didefinisikan sebagai bayi lahir saat dalam kandungan ibu atau saat masih berupa janin yang keluar dalam keadaan utuh tanpa memperhitungkan usia kehamilan ibu. Kematian ini mengindikasikan sebuah kenyataan 
bahwa keluarnya janin yang tidak bernafas atau tidak menunjukkan tanda-tanda kehidupan (detak jantung, denyut nadi pada tali pusar atau gerakan yang pasti dari otot polos). Biasanya Rumah Sakit melakukan pelaporan mengenai fetal death rate ini ke Dinas Kesehatan. Namun, cara pelaporan dan metode pelaporan memiliki beberapa bentuk dan metode sesuai dengan peraturan dan kebijakan tiap-tiap daerah.

Karena fetal detah rate ini tidak dianggap sebagai kematian pasien dan tidak termasuk dalam perhitungan kematian namun sebagai gantinya adalah dihitung secara terpisah. Penentuan apakah termasuk fetal death rate data atau bukan Rumah Sakit membutuhkan statistic yang spesifik dan memerlukan investigasi oleh administrasi RS, staf medis, dan bagian pelaporan RS. Fetal Death rate dapat diklasifikasikan berdasarkan tabel berikut:

\begin{tabular}{|l|l|l|}
\hline \multicolumn{1}{|c|}{ Klasifikasi } & \multicolumn{1}{c|}{ Usia Kehamilan } & \multicolumn{1}{c|}{ berat } \\
\hline Early Fetal Death & $<20$ minggu & $<500 \mathrm{gr}$ \\
\hline $\begin{array}{l}\text { Intermediate Fetal } \\
\text { Death }\end{array}$ & $\begin{array}{l}\text { Usia kehamilan 20- } \\
28 \text { minggu }\end{array}$ & $501-1000 \mathrm{gr}$ \\
\hline Late Fetal Death & 28 minggu & $>1000 \mathrm{gr}$ \\
\hline
\end{tabular}

Jika termasuk keduanya dari intermediate dan late fetal death sering disebut sebagai stillbirth. Rumus untuk menghitung fetal death adalah sebagai berikut:

$$
\frac{\text { Jumlah Lahir Mati dalam suatu periode }}{\text { Jumlah kelahiran pada periode tersebut }} \times 100 \%
$$




\section{Contoh:}

Selama bulan November, sebuah RS memiliki 207 kelahiran hidup, 1 early fetal death, 2 intermediate fetal death dan 3 late fetal death. Untuk menentukan fetal death rate dari RS, total jumlah intermediate dan late fetal death adalah 5 dikalikan 100 dan dibagi dengan jumlah lahir hidup dan intermediate dan late fetal death. Jadi perhitungannya adalah sebagai berikut:

$$
\frac{5 \times 100}{(207+5)}=2.36 \%
$$

\section{Soal-Soal}

1. Berdasarkan data berikut, hitunglah gross death rate (GDR) pada community hospital!

\begin{tabular}{l|c}
\multicolumn{1}{|c}{$\begin{array}{c}\text { Community Hospital } \\
\text { December 20XX Data }\end{array}$} \\
\hline Total adult and children live discharges & 645 \\
\hline Total adult and children deaths & 4 \\
\hline Total newborn live discharges & 87 \\
\hline Total newborn deaths & 1 \\
\hline
\end{tabular}

*kematian tidak termasuk dalam Discharge, gunakan 2 desimal dibelakang.

2. Profesional Manajemen Informasi Kesehatan melaporkan kepada komite Quality improvement di RS MIK bahwa terdapat 58 pasien dengan influenza keluar RS dalam keadaan hidup (discharge) pada bulan januari. Dari data tersebut 3 meninggal. Berapakah case fatality rate untuk influenza pada bulan januari? (gunakan 2 desimal setelah angka bukan pembulatan). 
3. Pada table berikut merupakan contoh laporan RS yang menunjukkan discharge dan meninggal. Hitung death rate tiaptiap tenaga medis dan total pada perempat tahun. Kematian tidak termasuk dalam discharge, hitung dengan 2 desimal terakhir dan bukan pembulatan!

\begin{tabular}{|c|c|c|c|}
\hline & 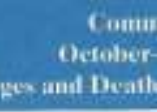 & 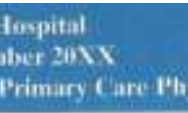 & \\
\hline Physiciun Number & $\begin{array}{l}\text { No, of Live } \\
\text { Discharges }\end{array}$ & No, of Deaths & Gross Death Rate \\
\hline Dr. 097 & 12 & 3 & \\
\hline Dr. 123 & 204 & 4 & \\
\hline Dr. 256 & 12 & 1 & \\
\hline Dr. 372 & 92 & 4 & \\
\hline Dr. 431 & 124 & 6 & \\
\hline Dr. 537 & 79 & 2 & \\
\hline Dr. 638 & 107 & 4 & \\
\hline Dr. 725 & 85 & 3 & \\
\hline Dr. 800 & 100 & 1 & \\
\hline Dr. 901 & 158 & 8 & \\
\hline Total & & & \\
\hline
\end{tabular}

4. Gunakan data pada table berikut untuk menghitung Net Death Rate (NDR) pada community hospital pada bulan April!

\begin{tabular}{|c|c|}
\hline $\begin{array}{l}\text { Coaminanity Uospital } \\
\text { April } 20 \times 2 \text { Deaths }\end{array}$ & \\
\hline Total adult and children live discharges & 409 \\
\hline Total adult and children deaths & 7 \\
\hline Deaths $<48$ hours & 2 \\
\hline Deaths $\geq 48$ hours & 5 \\
\hline Total newborn live discharges & 68 \\
\hline Total newborn deaths & 2 \\
\hline Deaths $<48$ bours & 1 \\
\hline Deaths $\geq 48$ hours & 1 \\
\hline
\end{tabular}


5. Gunakan table berikut untuk menghitung net death rate (NDR) pada tiap-tiap pelayanan dan total net death rate (Total NDR) pada community hospital berikut pada bulan desember!

\begin{tabular}{|c|c|c|c|c|}
\hline \multicolumn{5}{|c|}{$\begin{array}{l}\text { Community 11ospital } \\
\text { December 2IXX Dealls }\end{array}$} \\
\hline Service & $\begin{array}{l}\text { No. of Dischurges } \\
\text { (includes Deaths) }\end{array}$ & Total Deaths & $\begin{array}{c}\text { Deathes }<48 \\
\text { bours }\end{array}$ & $\begin{array}{l}\text { Net Death } \\
\text { Rate }\end{array}$ \\
\hline Medicine & 372. & 7 & 3 & \\
\hline Surgery & 301 & 4 & 3 & \\
\hline Psychiatric & 107 & 4 & 2 & \\
\hline Rehubilitation & 74 & 6 & 3 & \\
\hline Total & & & & \\
\hline
\end{tabular}

6. Dengan menggunakan table berikut, hitunglah Maternal death rate pada bulan mei pada community hospital berikut!

\begin{tabular}{|c|c|}
\hline & \\
\hline \multicolumn{2}{|c|}{ Discharges (Does not inclade deaths) } \\
\hline Delivered & 227 \\
\hline Aborted & 4 \\
\hline Undelivered, prepartum & 32 \\
\hline Undelivered, postpartum & 17 \\
\hline \multicolumn{2}{|l|}{ Deaths } \\
\hline Delivered & 1 \\
\hline Aborted & 2 \\
\hline Undelivered, prepartum & 1 \\
\hline Undelivered, postpartum & 2 \\
\hline
\end{tabular}

7. Bulan lalu, RSIA Delima merah hati melaporkan terdapat 123 pasien keluar RS (discharge) pada kasus obstetric dan 5 kematian (kematian termasuk discharge). Penyebab kematian tersebut adalah:

a. Kekerasan rumah tangga

b. Kecelakaan 
c. Bunuh Diri

d. Pendarahaan setelah Caesar

e. Pre-Eclamsia

Hitunglah angka kematian Ibu secara langsung (direct Maternal death rate) pada RS tersebut!

\section{Daftar Pustaka}

Ery Rustiyanto. (2010). Statistik rumah sakit untuk pengambilan keputusan. Graha IImu.

http://inlislite.dispusip.jakarta.go.id/dispusip/opac/det ail-opac?id=37915

Horton, L. A. (2017). Calculating and reporting healthcare statistics. /z-wcorg/.

http://search.ebscohost.com/login.aspx?direct=true\&s cope $=$ site $\& d b=$ nlebk $\& d b=$ labk $\& A N=1404208$

Huffman, E. K., Cofer, J., Association, A. M. R., \& Association, A. H. I. M. (1994). Health Information Management. Physicians' Record Company. https://books.google.co.id/books?id=tmxrAAAAMAAJ

Pulgar Perera VA, Paniagua Tejo MT, Sañudo García S. [Barber and Johnson diagram and latent reserve as tools to optimise the management of hospital beds]. Journal of Healthcare Quality Research. 2019 May - Jun;34(3):124-130. DOI: 10.1016/j.jhqr.2019.02.001.

Rano Indradi Sudra. (2010). Statistik rumah sakit: Dari sensus pasien, grafik Barber-Johnson hingga statistik kematian, otopsi, Perpustakaan Nasional RI. Graha IImu. https://opac. perpusnas.go.id/DetailOpac.aspx?id=6561 74\# 
Using health care data analytics to improve information management. (n.d.). SearchHealthIT. Retrieved September 18, 2020, from https://searchhealthit.techtarget.com/tutorial/Usinghealth-care-data-analytics-to-improve-informationmanagement

White, S. E. (2016). A Practical Approach to Analyzing Healthcare Data. American Health Information Management Association.

https://books.google.co.id/books?id=rp88jwEACAAJ 


\section{DAFTAR PUSTAKA}

Abdelhak Mervat et al., 2010, Health Information:Management Strategic of Resource, W.B. Saunders Company

Ery Rustiyanto. (2010). Statistik rumah sakit untuk pengambilan keputusan. Graha IImu.

http://inlislite.dispusip.jakarta.go.id/dispusip/opac/det ail-opac?id=37915

Horton, L. A. (2017). Calculating and reporting healthcare statistics. /z-wcorg/.

http://search.ebscohost.com/login.aspx?direct=true\&s cope $=$ site $\& d b=$ nlebk $\& d b=$ labk $\& A N=1404208$

Huffman, E. K., Cofer, J., Association, A. M. R., \& Association, A. H. I. M. (1994). Health Information Management.

Physicians' Record Company. https://books.google.co.id/books?id=tmxrAAAAMAAJ

Rano Indradi Sudra. (2010). Statistik rumah sakit: Dari sensus pasien, grafik Barber-Johnson hingga statistik kematian, otopsi, Perpustakaan Nasional RI. Graha IImu. https://opac. perpusnas.go.id/DetailOpac. aspx?id=6561 74\#

Using health care data analytics to improve information management. (n.d.). SearchHealthIT. Retrieved September 18, 2020, from https://searchhealthit.techtarget.com/tutorial/Usinghealth-care-data-analytics-to-improve-informationmanagement 
White, S. E. (2016). A Practical Approach to Analyzing Healthcare Data. American Health Information Management Association. https://books.google.co.id/books?id=rp88jwEACAAJ 


\section{BIODATA PENULIS}

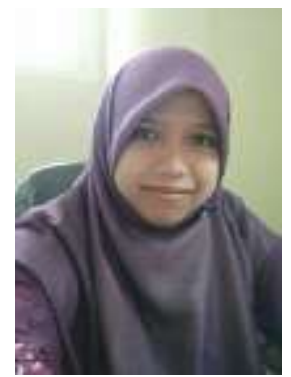

Umi Khoirun Nisak., S.KM., M. Epid. dilahirkan di Sidoarjo, 12 April 1988. Pada tahun 2010, penulis mendapatkan gelar Sarjana Kesehatan Masyarakat dari Universitas Airlangga Surabaya. Penulis melanjutkan Magister Epdemiologi dengan peminatan Manajemen Surveilans Epidemiologi dan Informasi Kesehatan (MSEIK). Tahun 2018, penulis secara resmi mendakatkan gelar M. Epid. Penulis mengawali karirnya di RS Swasta dan Salah satu RS pemerintah di Surabaya. Saat ini Penulis bekerja menjadi Dosen di prodi D-IV Manajemen Informasi Kesehatan Fakultas IImu Kesehatan di Universitas Muhammadiyah Sidoarjo.

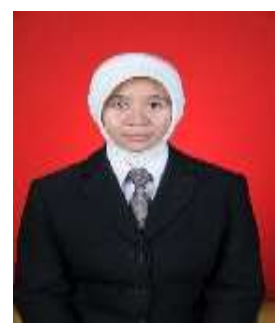

Cholifah, S.ST, M.Kes. lahir di Mojokerto 3 November 1981 telah menyelesaikan pendidikan formal di AKBID Siti Khodijah tahun 2003, lulus DIV Kebidanan Universitas Sebelas Maret (UNS) tahun 2007 dan telah menyelsaikan S2 di Universitas Diponegoro pada Tahun 2014. Saat ini bekerja di Universitas Muhammadiyah Sidoarjo Fakultas Ilmu Kesehatan sebagai dosen DIII kebidanan. Selain pendidikan dan pengajaran penulis juga terlibat dalam kegiatan penelitian dan pengabdian kepada masyarakat baik didanai oleh Internal UMSIDA maupun dana mandiri. Penulis juga aktif dalam mengikuti kegiatankegiatan penunjang akademik seperti seminar, workshop/ lokakarya, pelatihan serta pembimbingan tugas akhir dan kegiatan akademik. 
